Cochrane Database of Systematic Reviews

\title{
Osmotic therapies added to antibiotics for acute bacterial meningitis (Review)
}

Wall ECB, Ajdukiewicz KMB, Bergman H, Heyderman RS, Garner P

Wall ECB, Ajdukiewicz KMB, Bergman H, Heyderman RS, Garner P.

Osmotic therapies added to antibiotics for acute bacterial meningitis.

Cochrane Database of Systematic Reviews 2018, Issue 2. Art. No.: CD008806.

DOI: 10.1002/14651858.CD008806.pub3.

www.cochranelibrary.com

Osmotic therapies added to antibiotics for acute bacterial meningitis (Review)

Copyright $\odot 2018$ The Authors. Cochrane Database of Systematic Reviews published by John Wiley \& Sons, Ltd. on behalf of The Cochrane Collaboration. 
TABLE OF CONTENTS

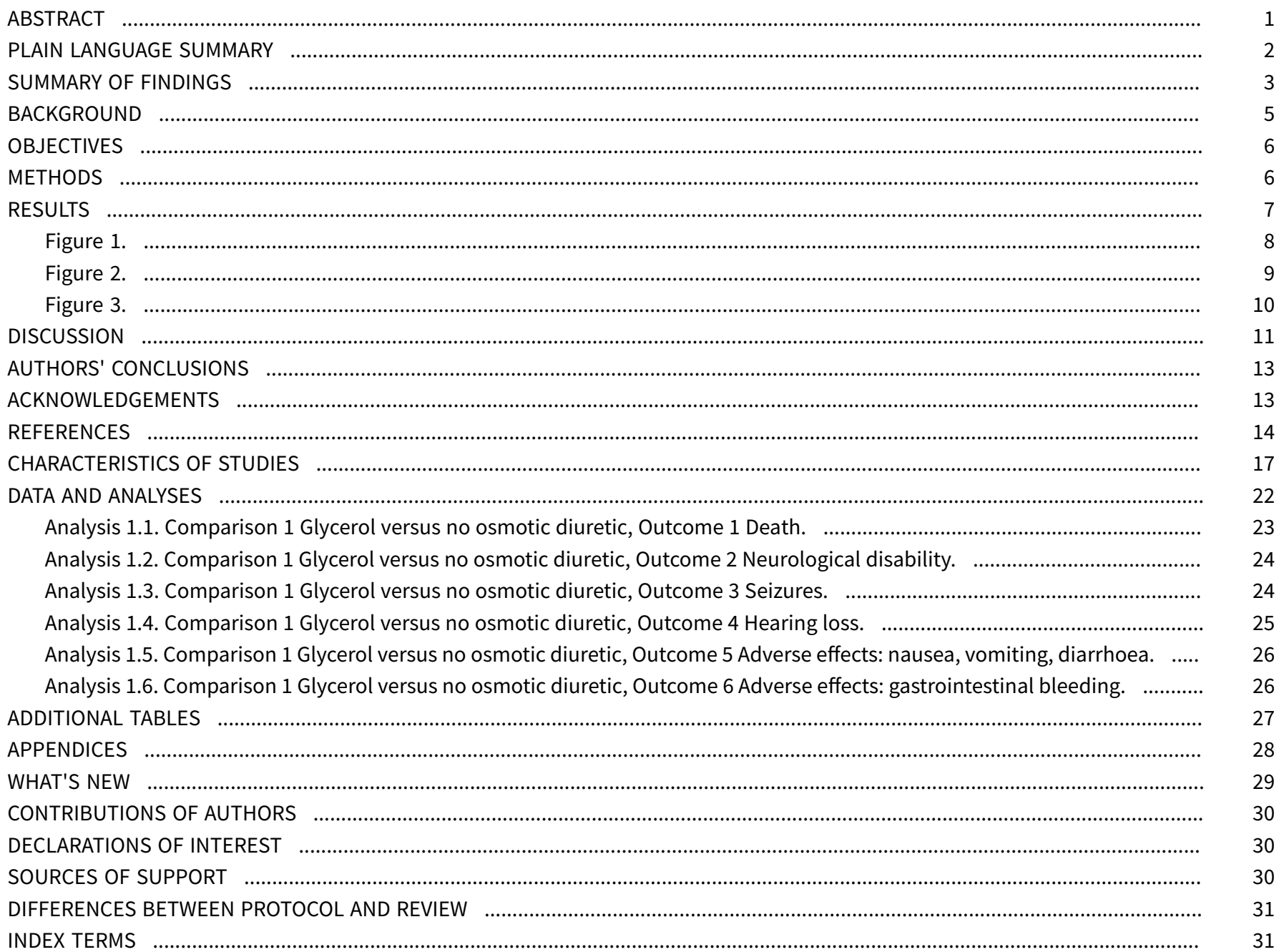


[Intervention Review]

\section{Osmotic therapies added to antibiotics for acute bacterial meningitis}

Emma CB Wall ${ }^{1}$, Katherine MB Ajdukiewicz ${ }^{2}$, Hanna Bergman ${ }^{3}$, Robert S Heyderman ${ }^{4}$, Paul Garner 5

1Division of Infection and Immunity, University College London, London, UK. 2Department of Infectious Diseases, Pennine Acute Hospitals NHS Trust, Manchester, UK. ${ }^{3}$ Cochrane Response, Cochrane, London, UK. ${ }^{4}$ Malawi-Liverpool-Wellcome Clinical Research Programme, University of Malawi College of Medicine, Blantyre, Malawi. ${ }^{5}$ Department of Clinical Sciences, Liverpool School of Tropical Medicine, Liverpool, UK

Contact: Emma CB Wall, Division of Infection and Immunity, University College London, Gower Street, London, WC1E 6BT, UK. e.wall@ucl.ac.uk,emma.wall@doctors.org.uk.

Editorial group: Cochrane Acute Respiratory Infections Group.

Publication status and date: New search for studies and content updated (no change to conclusions), published in Issue 2, 2018.

Citation: Wall ECB, Ajdukiewicz KMB, Bergman H, Heyderman RS, Garner P. Osmotic therapies added to antibiotics for acute bacterial meningitis. Cochrane Database of Systematic Reviews 2018, Issue 2. Art. No.: CD008806. DOI: 10.1002/14651858.CD008806.pub3.

Copyright ( 2018 The Authors. Cochrane Database of Systematic Reviews published by John Wiley \& Sons, Ltd. on behalf of The Cochrane Collaboration. This is an open access article under the terms of the Creative Commons Attribution Licence, which permits use, distribution and reproduction in any medium, provided the original work is properly cited.

\section{A B S T R A C T}

\section{Background}

Every day children and adults die from acute community-acquired bacterial meningitis, particularly in low-income countries, and survivors risk deafness, epilepsy and neurological disabilities. Osmotic therapies may attract extra-vascular fluid and reduce cerebral oedema, and thus reduce death and improve neurological outcomes.

This is an update of a Cochrane Review first published in 2013.

\section{Objectives}

To evaluate the effects of osmotic therapies added to antibiotics for acute bacterial meningitis in children and adults on mortality, deafness and neurological disability.

\section{Search methods}

We searched CENTRAL (2017, Issue 1), MEDLINE (1950 to 17 February 2017), Embase (1974 to 17 February 2017), CINAHL (1981 to 17 February 2017), LILACS (1982 to 17 February 2017) and registers of ongoing clinical trials (ClinicalTrials.com, WHO ICTRP) (21 February 2017). We also searched conference abstracts and contacted researchers in the field (up to 12 December 2015).

\section{Selection criteria}

Randomised controlled trials testing any osmotic therapy in adults or children with acute bacterial meningitis.

\section{Data collection and analysis}

Two review authors independently screened the search results and selected trials for inclusion. Results are presented using risk ratios (RR) and 95\% confidence intervals (CI) and grouped according to whether the participants received steroids or not. We used the GRADE approach to assess the certainty of the evidence.

\section{Main results}

We included five trials with 1451 participants. Four trials evaluated glycerol against placebo, and one evaluated glycerol against 50\% dextrose; in addition three trials evaluated dexamethasone and one trial evaluated acetaminophen (paracetamol) in a factorial design. Stratified analysis shows no effect modification with steroids; we present aggregate effect estimates. 
Compared to placebo, glycerol probably has little or no effect on death in people with bacterial meningitis ( $\mathrm{RR} 1.08,95 \% \mathrm{Cl} 0.90$ to 1.30 ; 5 studies, 1272 participants; moderate-certainty evidence), but may reduce neurological disability (RR $0.73,95 \% \mathrm{Cl} 0.53$ to $1.00 ; 5$ studies, 1270 participants; low-certainty evidence).

Glycerol may have little or no effect on seizures during treatment for meningitis (RR 1.08, 95\% $\mathrm{Cl} 0.90$ to 1.30; 4 studies, 1090 participants; low-certainty evidence).

Glycerol may reduce the risk of subsequent deafness (RR $0.64,95 \% \mathrm{Cl} 0.44$ to $0.93 ; 5$ studies, 922 participants; low to moderate-certainty evidence).

Glycerol probably has little or no effect on gastrointestinal bleeding (RR 0.93, 95\% Cl 0.39 to 2.19; 3 studies, 607 participants; moderatecertainty evidence). The evidence on nausea, vomiting and diarrhoea is uncertain (RR $1.09,95 \% \mathrm{Cl} 0.81$ to $1.47 ; 2$ studies, 851 participants; very low-certainty evidence).

\section{Authors' conclusions}

Glycerol was the only osmotic therapy evaluated, and data from trials to date have not demonstrated an effect on death. Glycerol may reduce neurological deficiency and deafness.

\section{PLAIN LANGUAGE SUMMARY}

\section{Osmotic therapies added to antibiotics for acute bacterial meningitis}

\section{What is the aim of this review?}

The aim of this Cochrane Review is to collect and analyse trials evaluating osmotic therapies given orally or intravenously to people with acute bacterial meningitis. Cochrane authors collected and analysed all relevant studies to answer this question; they found five relevant studies.

\section{Key messages}

Giving glycerol, an osmotic diuretic, probably has little or no effect on death (moderate-certainty evidence), but may reduce subsequent deafness (moderate-certainty evidence) or neurological disability (low-certainty evidence). The evidence is current to 17 February 2017.

\section{What was studied in the review?}

In meningitis, the cerebrospinal fluid that surrounds the brain and spinal cord is infected, usually as a result of spread from the blood. Any form of meningitis can result in death or severe disability, but acute bacterial meningitis is rapidly fatal without treatment. Even with antibiotics, $10 \%$ to $15 \%$ of children with bacterial meningitis die in high-income countries with much higher rates in low-income settings. The infection causes the brain to swell, and this is thought to contribute to death and to long-term brain damage in survivors. Osmotic therapies increase the concentration of the blood by exerting an osmotic pressure across a semi-permeable membrane (such as a cell wall or blood vessel lining in the brain). This draws water from the brain into the blood, thereby reducing pressure in the brain. Potentially osmotic therapies could increase the rate of survival, or they could do harm.

\section{What are the main results of the review?}

We included five trials that compared glycerol with placebo in a total of 1451 patients with bacterial meningitis. In the studies steroids were often given as well, but this did not appear to modify any of the effects seen with glycerol.

This review detected no benefit from glycerol relating to death. There appeared to be marginal protection against deafness and against neurological disability. No effect on epileptic seizures at follow-up was noted. Glycerol was not associated with any severe adverse effects. The number of trials included was small and only two tested a large number of participants. All trials were from different healthcare settings and examined either adults or children. 


\section{SUMMARY OF FINDINGS}

\section{Summary of findings for the main comparison. Glycerol for acute bacterial meningitis}

Glycerol for acute bacterial meningitis

Patient or population: children and adults with acute bacterial meningitis

Settings: Finland, India, South America, Malawi

Intervention: glycerol with or without steroids compared with placebo. All participants received broad-spectrum antibiotics

\begin{tabular}{|c|c|c|c|c|c|c|}
\hline \multirow[t]{3}{*}{ Outcomes } & \multicolumn{2}{|c|}{$\begin{array}{l}\text { Illustrative comparative risks* } \\
(95 \% \mathrm{Cl})\end{array}$} & \multirow[t]{3}{*}{$\begin{array}{l}\text { Relative effect } \\
(95 \% \mathrm{CI})\end{array}$} & \multirow{3}{*}{$\begin{array}{l}\text { Number of par- } \\
\text { ticipants } \\
\text { (studies) }\end{array}$} & \multirow{3}{*}{$\begin{array}{l}\text { Quality of the } \\
\text { evidence } \\
\text { (GRADE) }\end{array}$} & \multirow[t]{3}{*}{ Comments } \\
\hline & Assumed risk & $\begin{array}{l}\text { Corresponding } \\
\text { risk }\end{array}$ & & & & \\
\hline & Control & Glycerol & & & & \\
\hline Death & 19 per 100 & $\begin{array}{l}\mathbf{2 1} \text { per } \mathbf{1 0 0} \\
(17 \text { to } 25)\end{array}$ & $\begin{array}{l}\text { RR } 1.08 \\
(0.90 \text { to } 1.30)\end{array}$ & $\begin{array}{l}1272 \\
\text { (5 studies) }\end{array}$ & $\begin{array}{l}\oplus \oplus \oplus \ominus \\
\text { Moderate } 1,2,3,4\end{array}$ & $\begin{array}{l}\text { Downgraded for imprecision. } \\
\text { Glycerol probably has little or no effect on death }\end{array}$ \\
\hline $\begin{array}{l}\text { Neurological } \\
\text { disability }\end{array}$ & 9 per 100 & $\begin{array}{l}6 \text { per } 100 \\
(5 \text { to } 9)\end{array}$ & $\begin{array}{l}\mathbf{R R} \mathbf{0 . 7 3} \\
(0.53 \text { to } 1.00)\end{array}$ & $\begin{array}{l}1270 \\
\text { (5 studies) }\end{array}$ & $\begin{array}{l}\oplus \oplus \ominus \ominus \\
\text { Low } 1,3,4,5\end{array}$ & $\begin{array}{l}\text { Downgraded for imprecision and inconsistency. } \\
\text { Glycerol may reduce disability }\end{array}$ \\
\hline Seizures & 32 per 100 & $\begin{array}{l}35 \text { per } 100 \\
(29 \text { to } 42)\end{array}$ & $\begin{array}{l}\text { RR } 1.08 \\
(0.90 \text { to } 1.30)\end{array}$ & $\begin{array}{l}1090 \\
\text { (4 studies) }\end{array}$ & $\begin{array}{l}\oplus \oplus \ominus \ominus \\
\text { Low }^{1,3,4,6}\end{array}$ & $\begin{array}{l}\text { Downgraded for inconsistency and imprecision. } \\
\text { Glycerol may have little or no effect on seizures }\end{array}$ \\
\hline $\begin{array}{l}\text { Adverse ef- } \\
\text { fects: nausea, } \\
\text { vomiting, diar- } \\
\text { rhoea }\end{array}$ & 47 per 100 & $\begin{array}{l}\mathbf{5 1} \text { per } \mathbf{1 0 0} \\
\text { (38 to } 69)\end{array}$ & $\begin{array}{l}\text { RR } 1.09 \\
(0.81 \text { to } 1.47)\end{array}$ & $\begin{array}{l}851 \\
\text { ( } 2 \text { studies) }\end{array}$ & $\begin{array}{l}\oplus \ominus \ominus \ominus \\
\text { Very } \\
\text { low } 1,3,4,8,9\end{array}$ & $\begin{array}{l}\text { Downgraded for serious inconsistency and imprecision. } \\
\text { The effect of glycerol on adverse events: nausea, vomit- } \\
\text { ing and diarrhoea is uncertain }\end{array}$ \\
\hline $\begin{array}{l}\text { Adverse ef- } \\
\text { fects: gastroin- } \\
\text { testinal bleed- } \\
\text { ing }\end{array}$ & 3 per 100 & $\begin{array}{l}3 \text { per } 100 \\
(13 \text { to } 8)\end{array}$ & $\begin{array}{l}\text { RR } 0.93 \\
\text { (0.39 to } 2.19)\end{array}$ & $\begin{array}{l}607 \\
\text { (3 studies) }\end{array}$ & $\begin{array}{l}\oplus \oplus \oplus \odot \\
\text { Moder- } \\
\text { ate } 1,2,3,4\end{array}$ & $\begin{array}{l}\text { Downgraded for imprecision. } \\
\text { Glycerol probably has little or no effect on adverse } \\
\text { events: gastrointestinal bleeding }\end{array}$ \\
\hline
\end{tabular}


*The basis for the assumed risk (e.g. the median control group risk across studies) is provided in footnotes. The corresponding risk (and its $95 \%$ confidence interval (CI)) is based on the assumed risk in the comparison group and the relative effect of the intervention (and its $95 \% \mathrm{Cl}$ ).

Cl: confidence interval

RR: risk ratio

GRADE Working Group grades of evidence

High quality: Further research is very unlikely to change our confidence in the estimate of effect

Moderate quality: Further research is likely to have an important impact on our confidence in the estimate of effect and may change the estimate

Low quality: Further research is very likely to have an important impact on our confidence in the estimate of effect and is likely to change the estimate

Very low quality: We are very uncertain about the estimate

1 No serious risk of bias: allocation concealment was adequate in four trials and unclear (not reported) in one trial.

2Not downgraded for inconsistency.

${ }^{3}$ Not downgraded for indirectness. The five trials were conducted in Finland, Malawi, India and South America. Four were in children and one in adults. All included patients with suspected meningitis and cerebrospinal fluid (CSF) changes suggestive of bacterial infection.

4Downgraded by one level for imprecision: the $95 \% \mathrm{Cl}$ includes what might be a clinically important harm and no effect with glycerol.

5Downgraded by one level for inconsistency: in the Finnish trial the risk of neurological sequelae was reduced with glycerol (RR $0.50,95 \% \mathrm{Cl} 0.32$ to $0.78, \mathrm{~N}=329)$, but this was not found in the other studies and the meta-analysis did not detect a difference $\left(I^{2}=59 \%\right)$

${ }^{6}$ Downgraded by one level for inconsistency: in the trial with adults the risk of seizures was higher with glycerol ( $\mathrm{RR} 1.62,95 \% \mathrm{Cl} 1.18$ to $\left.2.23, \mathrm{~N}=250\right)$, but this was not found in the other studies and the meta-analysis did not detect a difference $\left(I^{2}=62 \%\right)$.

7Downgraded by one level for imprecision: the number of patients with reported hearing loss was low in these studies and the $95 \% \mathrm{Cl}$ includes both no effect and what might be a clinically important benefit with glycerol. Larger studies would be necessary to have full confidence in this effect.

${ }^{8}$ Another two trials reported on this outcome but the results could not be added to the meta-analysis; one reported more cases of vomiting with glycerol and the other that the incidence of vomiting was "similar" in the treatment groups.

${ }^{9}$ Downgraded by two levels for inconsistency: in the South American and Finnish trials the risk of adverse effects was increased with glycerol, but this was not found in the Malawi and India trials, and the meta-analysis did not detect a difference $\left(I^{2}=79 \%\right)$. 


\section{B A C K G R O U N D}

\section{Description of the condition}

Community-acquired acute bacterial meningitis is a devastating infection with associated rates of death and disability that have changed little over the last 10 to 15 years. In high-income countries, $5 \%$ to $30 \%$ of adult patients die, rising to $50 \%$ to $60 \%$ in low-income countries, despite highly effective antibiotics against the causative pathogens (de Gans 2002; Nguyen 2007; Scarborough 2007). The high mortality is predominately seen in Streptococcus pneumoniae (S pneumoniae) infections; meningitis caused by Neisseria meningitidis ( $N$ meningitidis) carries a lower mortality. In children, a wider range of pathogens are noted and the case fatality rate is lower (Harnden 2006; Molyneux 2006; Pelkonen 2009; Peltola 2009; Roine 2009). Nevertheless, some survivors develop neurological problems that may be permanent. The most common meningitis sequelae are deafness, epilepsy and poor cognitive development (Molyneux 2002; Nguyen 2007; van de Beek 2009), thought to be caused by infection-induced inflammation, thrombosis and brain oedema (swelling). The outcome from bacterial meningitis is influenced by the pathogen, the geographical area, the patient's access to healthcare and the quality of the healthcare system. There are very few data on risk factors for poor outcomes in low-income countries. However, anaemia and delayed presentation to hospital are probably important (McCormick 2012; Sudarsanam 2017). HIV may influence outcomes but the role of the virus in pathogenesis is not yet clearly understood (Domingo 2009). High mortality rates, despite effective antibiotics, have led investigators to try and minimise neurological inflammation with adjunctive therapies.

Increasing understanding of the pathways of cerebral inflammation in meningitis has led several investigators to try treatments that aim to reduce brain oedema and inflammation and improve brain perfusion. The intervention most extensively tested in clinical trials has been corticosteroids. A Cochrane Review shows a mortality benefit in adults in Europe with meningitis due to $S$ pneumoniae and an overall reduction in deafness in adults and children (Brouwer 2015). Another systematic review of individual patient data from five randomised studies suggests that the effect of dexamethasone on outcomes for bacterial meningitis in these countries is limited to reducing the incidence of hearing loss in survivors (van de Beek 2010). A long-held concern exists over excessive fluids contributing to brain oedema; a further Cochrane Review suggests that judicious fluid resuscitation guided by the clinical condition is appropriate to maximise brain perfusion without contributing to brain oedema (Maconochie 2016).

\section{Description of the intervention}

Osmotic therapies work by increasing the concentration of the blood. They exert an osmotic pressure across a semi-permeable membrane (such as a cell wall or blood vessel lining in the brain), which draws water from the brain into the blood and reduces pressure in the brain. This is theoretically advantageous if brain swelling is causing reduction in brain function.

Osmotic therapies have long been used in acute brain trauma (BTF 2000), and their use has been postulated in other forms of acute brain injury, particularly stroke (Bereczki 2007; Yu 1992; Yu 1993) and cerebral malaria (Namutangula 2007; Okoromah 2011). Mannitol and hypertonic saline are the most commonly used osmotic therapies (Wakai 2013), but glycerol, sorbitol and sodium lactate have also been investigated (Righetti 2004; Stoll 1998). Details of all these therapies are reported in Table 1. Glycerol has been studied in animals with meningitis, where no effect was noted. Conclusions from these studies are limited by the applicability of animal models of meningitis, where set doses of pathogenic bacteria are introduced directly into the animal's central nervous system, to the complex host pathogen interactions in human disease (Blaser 2010; Schmidt 1998). The excellent safety profile of glycerol in previous studies (Righetti 2004), combined with its low cost and easy administration and availability, has led investigators to look for its efficacy as an adjuvant treatment in acute bacterial meningitis in both adults and children, particularly in low-income countries.

\section{How the intervention might work}

All osmotic therapies have slightly different and poorly understood mechanisms of action. The osmotic drug's mechanism of action causes dehydration of central nervous system (CNS) cells, lowering intracranial pressure (ICP). However this effect may only be temporary and lead to a rebound phenomenon where cells subsequently draw in too much water, increasing the oedema. Mannitol has this mechanism of action but acts primarily by erythrocyte deformity through increases in intravascular water, allowing increased tissue oxygenation in the CNS. Mannitol produces a large diuresis through this effect, which causes a reflex cerebral vasoconstriction, temporarily reducing ICP. However, there is a significant risk of subsequent rebound raised ICP and mannitol is now used sparingly due to this concern. The main mechanism of action of glycerol in humans is unknown but there are some data to suggest that the addition of glycerol in meningitis could potentially improve cerebral blood flow and metabolism (Mathew 1972; Meyer 1972). Glycerol also has a mild effect on serum osmolality (Singhi 2008).

Hypertonic saline and sodium lactate appear to have direct osmotic actions on cells and they do not cause diuresis. These drugs may therefore be better than mannitol in reducing ICP (Ichai 2009). Osmotic diuretics such as mannitol and sorbitol could potentially also have a clinical benefit in meningitis through reduction in ICP but may risk volume depletion in the febrile patient. All osmotic therapies ideally require an intact blood brain barrier to exert their effects. Bacterial meningitis causes disruption of the barrier due to intense inflammation in the subarachnoid space and therefore it cannot be assumed that osmotic therapies would be beneficial. Table 1 gives details of all the properties of currently available osmotic therapies.

\section{Why it is important to do this review}

To date, there have been a few placebo-controlled studies using osmotic therapies in meningitis published in different settings in children and adults. A systematic review and meta-analysis would help to decide if these studies have demonstrated clinical benefit either by improvement in mortality or long-term neurological disabilities from the use of these treatments. This review aimed to encompass all types of osmotic therapies to investigate whether the principle of osmotic pressure change in the CNS is of benefit in people with meningitis and to demonstrate whether osmotic therapies should be recommended in principle, or if a particular therapy should be recommended in the treatment of acute bacterial meningitis. 


\section{O B JECTIVES}

To evaluate the effects of osmotic therapies added to antibiotics for acute bacterial meningitis in children and adults on mortality, deafness and neurological disability.

\section{METHODS}

\section{Criteria for considering studies for this review}

\section{Types of studies}

Randomised controlled trials (RCTs).

\section{Types of participants}

Adults and children diagnosed with acute community-acquired bacterial meningitis, as defined by the trial authors, on the basis of cerebrospinal fluid (CSF) culture, white cell count, biochemical composition and clinical presentation.

\section{Types of interventions}

Intervention: osmotic therapy, including at least one of the following: orally administered glycerol, intravenous (IV) hypertonic saline, sodium lactate and osmotic diuretics including IV mannitol and sorbitol.

Control: standard IV therapy or matched placebo.

All participants received broad-spectrum intravenous antibiotic treatment.

\section{Types of outcome measures}

\section{Primary outcomes}

1. All-cause mortality.

\section{Secondary outcomes}

1. Residual neurological deficit at the end of the follow-up period, including focal neurological deficit, epilepsy and deafness. Deafness was defined as hearing loss greater than 40 decibels bilaterally.

2. Epilepsy/seizures.

3. Deafness (hearing loss greater than 40 decibels bilaterally).

4. Adverse effects.

\section{Search methods for identification of studies}

\section{Electronic searches}

We searched the Cochrane Central Register of Controlled Trials (CENTRAL 2017, Issue 1), part of the Cochrane Library, www.thecochranelibrary.com (accessed 17 February 2017), which contains the Acute Respiratory Infections Group's Specialised Register, MEDLINE (Ovid) (1950 to 17 February 2017), Embase (Elsevier) (1974 to 17 February 2017), LILACS (BIREME) (1982 to 17 February 2017) and CINAHL (Ebsco) (1981 to 17 February 2017).

We used the search terms described in Appendix 1 to search MEDLINE and CENTRAL. We combined the MEDLINE search strategy with the Cochrane Highly Sensitive Search Strategy for identifying randomised trials in MEDLINE: sensitivity-maximising version (2008 revision); Ovid format (Lefebvre 2011). We adapted the search strategy to search Embase (Appendix 2), CINAHL (Appendix 3) and LILACS (Appendix 4).

\section{Searching other resources}

We searched the following clinical trials registers on 21 February 2017.

1. ClinicalTrials.gov (www.clinical trials.gov) (Appendix 5).

2. World Health Organization International Clinical Trials Registry Portal (WHO ICTRP, www.who.int/ictrp/en/) (Appendix 6).

For previous versions of this review we also searched conference abstracts and contacted researchers in the field (to 12 December 2015).

\section{Data collection and analysis}

\section{Selection of studies}

One author (EW) screened all search results (title and abstract) and selected relevant studies according to the review inclusion criteria. Two authors (EW, KA) screened all selected studies by reading the published full text to ensure each study met the inclusion criteria. The same two authors then agreed which studies were to be included in the review. We emailed trial authors to clarify duplication and study numbers.

\section{Data extraction and management}

Two review authors (EW, KA) independently extracted all data from the selected studies using a data extraction form. We discussed all trial data, which were then included only when the data matched those extracted by both review authors. We contacted one trial author regarding duplication and we excluded one study from the analysis as a result. No further discrepancies arose during data extraction. We entered data for analysis using RevMan 5.3 software (Review Manager 2014).

\section{Assessment of risk of bias in included studies}

The data extraction form included a 'Risk of bias' collection tool. Two review authors (EW, KA) independently judged the potential risk of bias for each included study as low, uncertain or high for the following parameters (Higgins 2011). Both review authors then discussed and agreed the final judgements. One review author (EW) synthesised these judgements into a standard 'Risk of bias' table for each study. See Characteristics of included studies.

1. Random sequence generation.

2. Allocation concealment.

3. Blinding.

4. Incomplete outcome data.

5. Selective reporting of outcome data.

6. Other identified areas of bias particular to that study (e.g. if the principal investigator was employed by the pharmaceutical company manufacturing the drug under investigation, or if the study is sponsored by a pharmaceutical company).

\section{Measures of treatment effect}

The primary outcome of this review was binary and the studies included were all RCTs, therefore we used the risk ratio (RR) as the most appropriate statistical tool to express the results of the 
treatment effect in a meta-analysis. We displayed the results as forest plots.

All included studies had outcomes defined by the trial authors using standardised measurements. We counted hearing loss of greater than 40 decibels $(\mathrm{dB})$ as significant where measured. If a formal neurological score was used to define neurological disability we used this. However, where only a description was given, we counted a described deficit that results in the participant not being able to work or attend school as significant. As the number of studies was small we were not able to analyse mortality by continental geographical area and resource setting as secondary outcomes, as planned in the protocol.

Due to the small number of studies retrieved, we were unable to group results for both primary and secondary outcomes by the follow-up period: acute phase, less than three months since inclusion in the study and longer-term up to one year of follow-up.

\section{Unit of analysis issues}

We did not anticipate any cluster-randomised trials on this topic. However, within the trials included, a four parallel-arm design was employed. We separated data into groups comparing the intervention alone with placebo, and the intervention plus a second intervention with the second intervention alone. These results are expressed in Analysis 1.1 and Analysis 1.4.

\section{Dealing with missing data}

We found some relevant data to be missing from Kilpi 1995, Sankar 2007 and Molyneux 2014. We contacted the authors for clarification or additional data. Molyneux provided information and data; we did not receive responses from Kilpi or Sankar.

\section{Assessment of heterogeneity}

We intended to use the $\mathrm{I}^{2}$ statistic and to explore explanations for heterogeneity by subgroup analysis as outlined in the protocol, but the data were insufficient.

\section{Assessment of reporting biases}

We assessed each study for reporting bias. Where it was suspected that selected results had been presented, we contacted the authors for clarification (see Dealing with missing data).

\section{Data synthesis}

We entered all extracted data into RevMan 5.3 (Review Manager 2014) and performed all analyses using this software. We expressed all results using forest plots. We used a fixed-effect model for analysis and found minimal heterogeneity between the studies. We repeated the analyses using a random-effects model where heterogeneity was detected. We present the results from the fixedeffect model. Where disagreement in effect size was determined between the fixed-effect and random-effects models, we present data from both models.

\section{GRADE and 'Summary of findings' table}

We created Summary of findings for the main comparison using the following outcomes: death, neurological disability, seizures, hearing loss and adverse effects. We used the five GRADE considerations (study limitations, consistency of effect, imprecision, indirectness and publication bias) to assess the quality of evidence as it related to the studies that contributed data to the meta-analyses for the prespecified outcomes (Atkins 2004). We used the methods and recommendations described in Section 8.5 and Chapter 12 of the Cochrane Handbook for Systematic Reviews of Interventions (Higgins 2011) using GRADEpro GDT software (GRADEpro GDT 2014). We justified all decisions to downgrade or upgrade the quality of studies in footnotes, and made comments to aid readers' understanding of the review where necessary.

\section{RE S U L T S}

\section{Description of studies}

\section{Results of the search}

We obtained 31 records from the 2017 update search; two duplicates were excluded. We assessed 29 records and could exclude 19 titles and abstracts. We obtained five full texts and excluded four. We included one new study in this update (Molyneux 2014).

We screened a total of 752 abstracts following the initial search in November 2010. Further records were screened following update searches in November 2012 (35 records from electronic databases), November 2014 (24 records) and February 2017 (24 records from electronic databases and five records from trials databases). This resulted in 840 screened abstracts in total over the history of this review including updates. See Figure 1. 
Figure 1. Study screening flow diagram

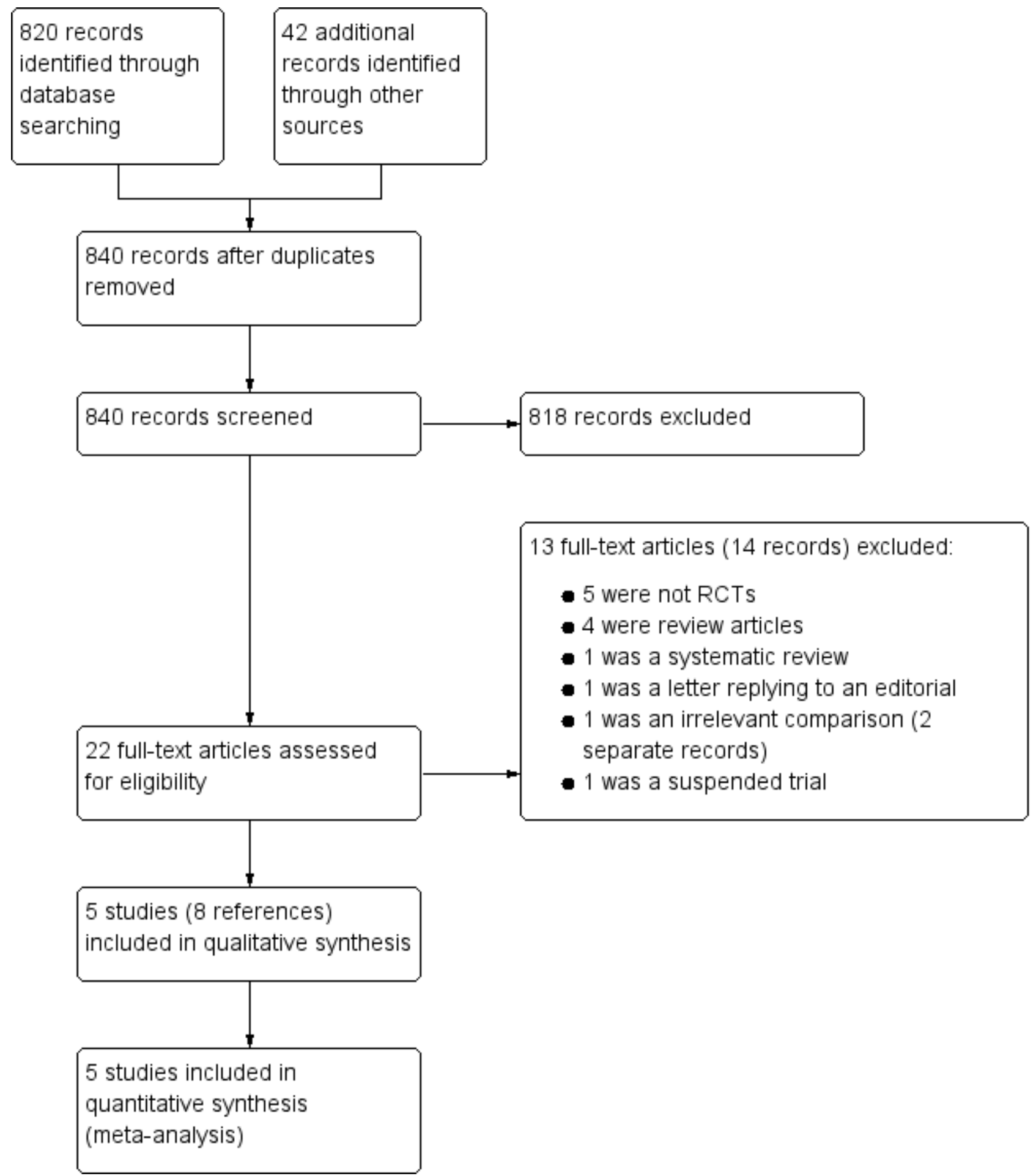

\section{Included studies}

Five trials, published in eight trial reports, with a total of 1451 participants met the inclusion criteria (Ajdukiewicz 2011; Kilpi 1995; Molyneux 2014; Peltola 2007; Sankar 2007). Molyneux 2014 was added at this update and included 181 participants. We extracted no data from a companion paper to Sankar 2007; it reported osmolarity data for a subset. We similarly extracted no data from a companion paper to Peltola 2007; it reported on deafness in more detail.

All included studies tested glycerol compared to matched placebo, with some studies including a dexamethasone arm and one study an acetaminophen (paracetamol) arm. 


\section{Study funding sources}

Four studies were funded by research foundations (Ajdukiewicz 2011; Kilpi 1995; Molyneux 2014; Peltola 2007) and of these, two studies were also partially funded by the pharmaceutical industry (Kilpi 1995; Peltola 2007). One study reported no funding (Sankar 2007).

\section{Participants}

Four trials were conducted in children aged under 16 years (Kilpi 1995; Molyneux 2014; Peltola 2007; Sankar 2007) and one in adults and adolescents aged over 14 years (Ajdukiewicz 2011).

\section{Interventions}

All included studies used oral glycerol as the primary intervention. The potential mechanism of action of glycerol is detailed in Table 1. The four trials in children evaluated glycerol alone, dexamethasone alone, glycerol combined with dexamethasone and glycerol combined with paracetamol. These studies used intravenous (IV) placebo to 'blind' the dexamethasone treatment group. No placebo for oral glycerol was used in Kilpi 1995 and Sankar 2007. Peltola 2007 and Molyneux 2014 used oral carboxymethylcellulose as a placebo for glycerol.

The adult study used $50 \%$ dextrose as an oral placebo agent to compare to glycerol diluted in water or $50 \%$ dextrose (Ajdukiewicz 2011).

\section{Location}

Kilpi 1995 took place in Finland, Peltola 2007 in South America (multiple sites), Sankar 2007 in India and both Ajdukiewicz 2011 and Molyneux 2014 in Malawi.

\section{Outcomes}

Death was the primary outcome in all included studies.
In Peltola 2007, we noted different results in tables 2 and 3 . As there appeared to be exclusions in table 3 , we used the data from table 2 , which appeared to be intention-to-treat.

\section{Excluded studies}

We excluded 13 studies (14 records). We found that 11 studies, which each used or mentioned the use of osmotic therapies, were not randomised controlled trials (RCTs) and these were excluded. Reasons for exclusion were as follows:

- five studies were not randomised trials;

- four were review articles;

- one was a systematic review (we screened the reference list and found no new studies to include in our review); and

- one was a letter replying to an editorial comment.

We also excluded one study that included children with acute central nervous system infections and raised intracranial pressure (ICP) randomised to receive cerebral perfusion pressuretargeted therapy or intracranial pressure-targeted therapy (Kumar 2014); and one study that was a registered trial record (CTRI/2015/04/005668). The trial registry stated that it had been suspended and this was confirmed with the trialists. See Figure 1 for a flow diagram of the study selection process.

\section{Studies awaiting classification}

There are currently no studies awaiting classification.

\section{Ongoing studies}

We did not identify any ongoing studies.

\section{Risk of bias in included studies}

Risk of bias was mostly low; $70 \%$ of our judgements were of low risk of bias (see Figure 2). See Figure 3 for our judgements for each risk of bias item for each included study.

Figure 2. 'Risk of bias' graph: review authors' judgements about each risk of bias item presented as percentages across all included studies

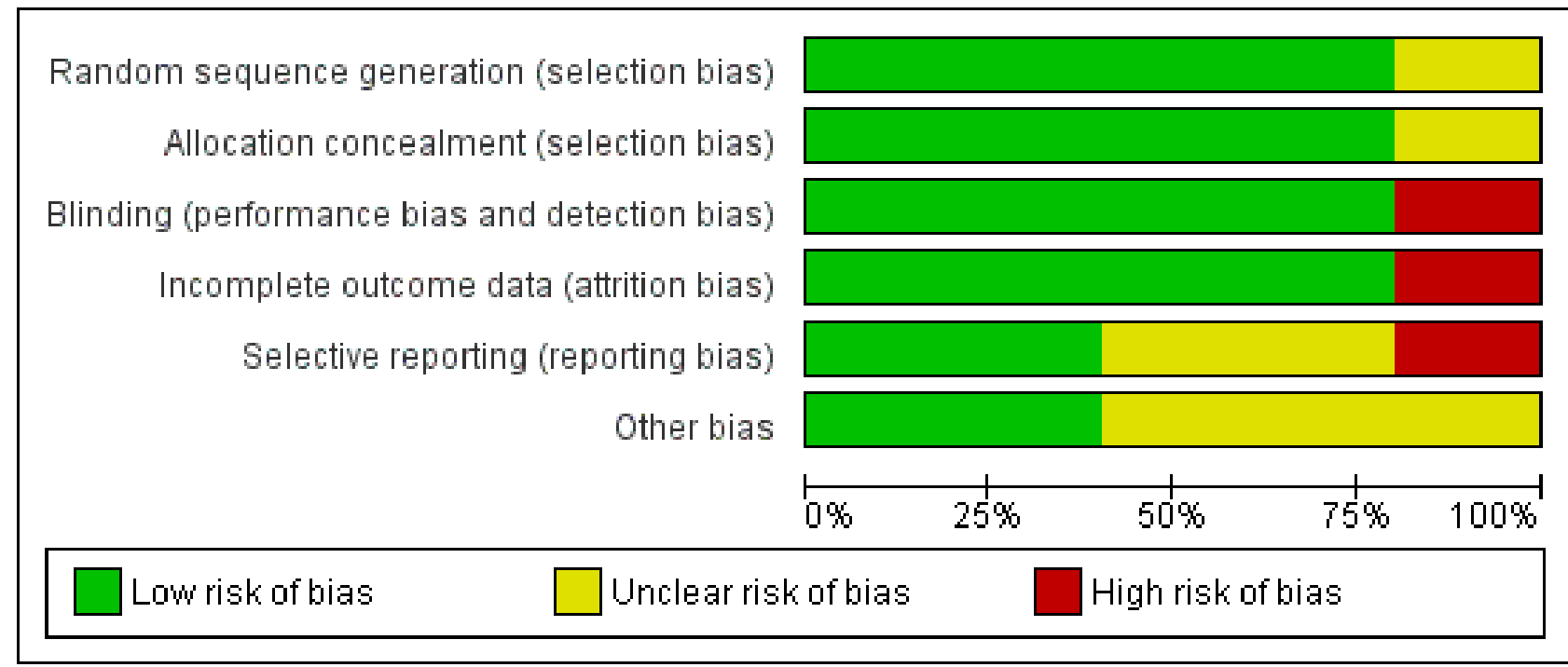


Figure 3. 'Risk of bias' summary: review authors' judgements about each risk of bias item for each included study

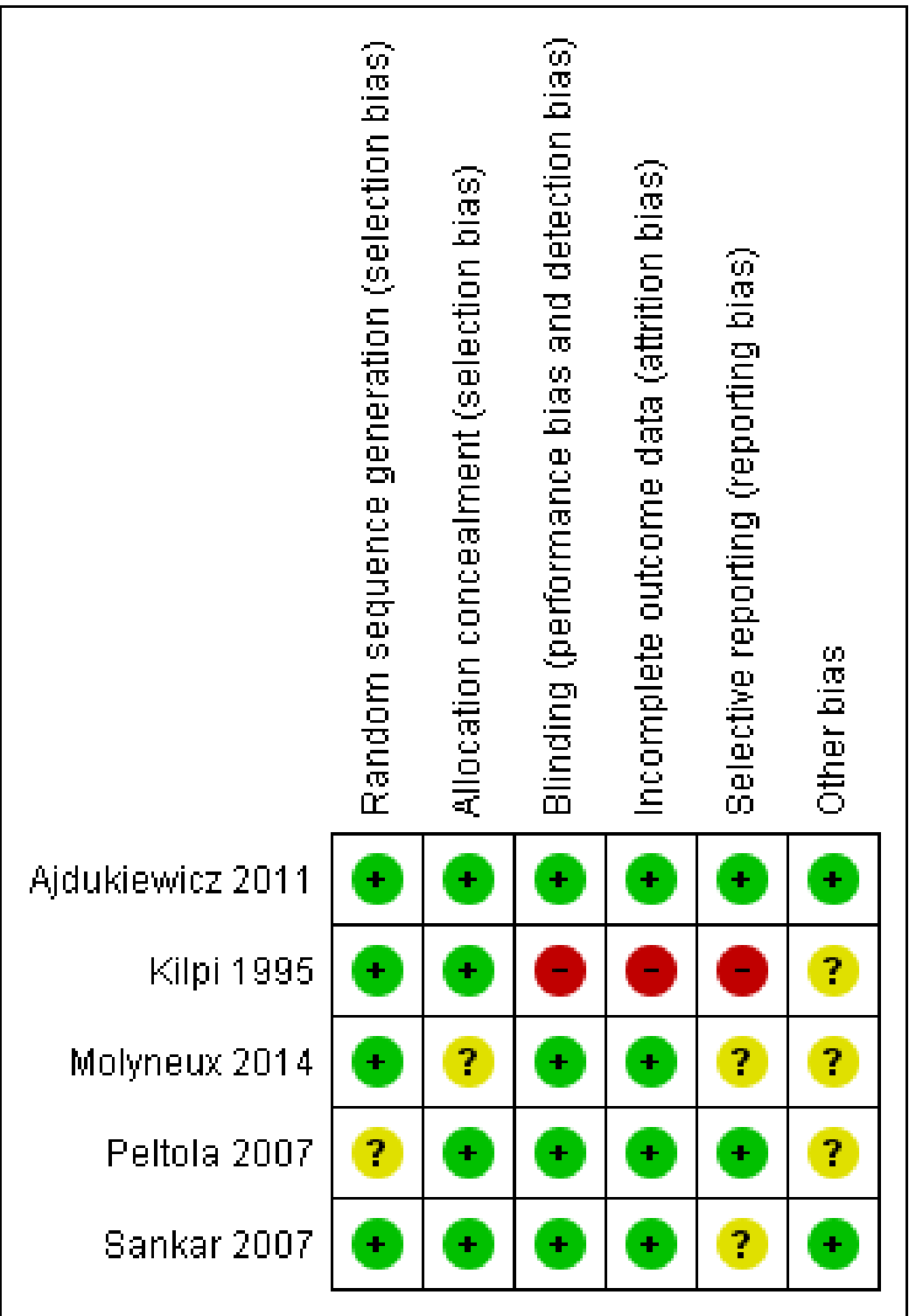

\section{Allocation}

The risk of bias was low for random sequence generation across all studies. Allocation concealment was adequately described for all but one study (Molyneux 2014), which we judged at unclear risk of bias (Figure 2 and Figure 3). We judged Peltola 2007 at unclear risk of allocation bias due to changes in the protocol that occurred during the study, a change from two dexamethasone to one placebo to one dexamethasone to one placebo, as reported by a meta-analysis of individual patient data testing dexamethasone compared to placebo for bacterial meningitis (van de Beek 2010).

\section{Blinding}

The risk of bias was low for blinding across four studies. We judged Kilpi 1995 at high risk of performance and detection bias, as no details of any concealment were given, so we assumed that the allocations were not blinded (Figure 2). The review authors requested clarification from the authors of Kilpi 1995 but no response has been received.

\section{Incomplete outcome data}

Four studies reported complete data and we judged them to have a low risk of attrition bias. Data on two participants were missing from Kilpi 1995 and we judged this study to have a high risk of attrition bias.

\section{Selective reporting}

We judged Ajdukiewicz 2011 and Peltola 2007 to have a low risk of reporting bias as all data appeared to be presented clearly and completely. Kilpi 1995 presented selected data as there was significant attrition bias, so we judged it to have a high risk of reporting bias. We judged Sankar 2007 to have an unclear risk of reporting bias as neither adverse effects nor time of stopping treatment were presented. Kilpi 1995 did not respond to our request for data on all enrolled trial participants. 


\section{Other potential sources of bias}

No trials were sponsored by pharmaceutical companies, nor were the authors declared to have conflicts of interest. Peltola 2007 was partly funded by a pharmaceutical company, which supplied the dexamethasone for the trial but not the glycerol, so we did not judge this to have a significant bias effect on this analysis. Kilpi 1995 was also partially funded by a pharmaceutical company and we judged the risk of bias as unclear.

\section{Effects of interventions}

See: Summary of findings for the main comparison Glycerol for acute bacterial meningitis

We included five trials, all evaluating glycerol. Four of the trials had four arms, which also compared glycerol plus dexamethasone with dexamethasone alone or glycerol plus paracetamol and paracetamol alone.

We carried out the initial analysis comparing participants who received glycerol or placebo only, or glycerol with paracetamol or placebo with paracetamol, labelled 'no steroids'. We carried out a subgroup analysis with the remaining trial participants who received either glycerol plus dexamethasone or dexamethasone plus placebo, labelled 'with steroids'. All trial participants received the antibiotic ceftriaxone, so no antibiotic subgroup analysis was necessary. Due to the small number of included studies, a subgroup analysis of paediatric data was not possible.

\section{Primary outcome}

\section{All-cause mortality}

In the adult study, there were more deaths in the glycerol group and this led to the study being stopped by the data monitoring committee (risk ratio (RR) 1.30, 95\% confidence interval (CI) 1.04 to 1.62) (Ajdukiewicz 2011). None of the other studies detected harm with glycerol and the meta-analysis did not detect an effect on mortality (RR $1.08,95 \% \mathrm{Cl} 0.90$ to 1.30, 1272 participants, 5 trials, $1^{2}=17 \%$, Analysis 1.1, moderate-certainty evidence). The stratified analysis found no significant difference whether dexamethasone was administered or not.

\section{Secondary outcomes}

\section{Residual neurological deficit at the end of the follow-up period}

Overall, a slight reduction (54/644 cases) in neurological disability was reported in the glycerol group compared with the placebo group (77/626) (RR $0.73,95 \% \mathrm{Cl} 0.53$ to $1.00,1270$ participants, 5 trials, $I^{2}=50 \%$, Analysis 1.2, low-certainty evidence). The effect size was further reduced using the random-effects model (RR 0.70, 95\% $\mathrm{Cl} 0.38$ to 1.27). Little or no difference was detected in the subgroup of participants who received steroids (RR $0.82,95 \% \mathrm{Cl} 0.38$ to 1.77 , 419 participants, 3 trials, $\left.\right|^{2}=25 \%$ ).

\section{Epilepsy/seizures}

Convulsions on admission and during treatment were reported in all studies but none reported data for persistent epileptic seizures post discharge. In the adult study, the risk of seizures was higher with glycerol (RR 1.62, 95\% Cl 1.18 to 2.23) (Ajdukiewicz 2011). However, this was not found in the other studies and the metaanalysis did not detect a difference (RR $1.08,95 \% \mathrm{Cl} 0.90$ to 1.30 ;
1090 participants, 4 trials, $\mathrm{I}^{2}=54 \%$, Analysis 1.3 , low-certainty evidence).

\section{Deafness}

Fewer surviving participants given glycerol were reported as deaf at four to eight weeks of follow-up compared to placebo (RR 0.64, $95 \% \mathrm{Cl} 0.44$ to $0.93 ; 5$ trials, 922 participants, $\mathrm{I}^{2}=7 \%$, Analysis 1.4 , moderate-certainty evidence). Using the random-effects model, the estimate of the effect size of glycerol on deafness was slightly lower (RR $0.67,95 \% \mathrm{Cl} 0.44$ to 1.01 ).

\section{Adverse effects}

Neither glycerol nor dexamethasone were associated with significant adverse effects in the included studies but systematic recording of adverse events was not reported. Only Ajdukiewicz 2011 reported on serious adverse events (SAEs). One SAE was reported each in glycerol and placebo arm participants, both considered possibly due to the study drug but the researchers reported that the most likely diagnosis for both participants (HIVpositive adults in Malawi) was a major cerebrovascular event secondary to meningitis.

Common adverse effects were nausea and vomiting; there were also small numbers of cases of gastrointestinal bleeding.

\section{Nausea, vomiting, diarrhoea}

Two studies reported on nausea, vomiting or diarrhoea, with $221 / 426$ events in the glycerol groups and 200/425 in the placebo groups. The meta-analysis did not detect a difference (RR 1.09, 95\% $\mathrm{Cl} 0.81$ to $1.47 ; 2$ trials, 851 participants, $\mathrm{I}^{2}=79 \%$, Analysis 1.5, very low-certainty evidence) but heterogeneity was high. Peltola 2007, a study conducted with children in South America, reported more adverse events in the glycerol without steroids group (80/148) than in the placebo group (53/148) (RR 1.51, 95\% Cl 1.16 to 1.96; 296 participants).

Two studies reported results that could not be added to the metaanalysis. Sankar 2007, a study conducted with children in India, reported that the incidence of vomiting in the glycerol and nonglycerol groups was "similar", and Kilpi 1995, a trial with children conducted in Finland, reported a higher incidence of vomiting on days 2 and 3 in the glycerol and glycerol with steroid groups (day 2: $38 \%$, day $3: 23 \%$ ) than in the steroid and placebo groups (day 2: $14 \%$, day $3: 4 \%$ ) and that vomiting led to discontinuation of glycerol treatment in three cases.

\section{Gastrointestinal bleeding}

Overall, 10 cases (3\%) of gastrointestinal bleeding were reported in each of the glycerol and placebo groups. The meta-analysis did not detect a difference (RR $0.93,95 \% \mathrm{Cl} 0.39$ to 2.19; 3 trials, 607 participants, $\mathrm{I}^{2}=0 \%$, Analysis 1.6 , moderate-certainty evidence).

\section{DISCUSSION}

\section{Summary of main results}

We included five trials evaluating glycerol in acute bacterial meningitis. Other osmotic diuretics, such as mannitol and hypertonic saline, have not yet been tested.

Glycerol was tested in adults and children with acute bacterial meningitis in a variety of different clinical settings and in four of 
the five included trials, glycerol was evaluated in a complex trial design including dexamethasone or acetaminophen. The review and meta-analysis did not detect an overall effect of glycerol on mortality from acute bacterial meningitis in children and adults. However, in the only trial in adults, glycerol was associated with increased mortality. We assessed the quality of the evidence using GRADE criteria as low (GRADEpro GDT 2014; Summary of findings for the main comparison).

The meta-analysis of low-quality evidence suggested that glycerol may reduce hearing loss (Summary of findings for the main comparison).

The small numbers seen overall in the studies in children were not sufficient to fully exclude the impact of dexamethasone, particularly on neurological disabilities and deafness in children, as this has been shown to be effective elsewhere (van de Beek 2010).

The overall number of study participants in this review was small and a significant degree of bias was found to be present in Kilpi 1995. Analysis was mainly weighted on Ajdukiewicz 2011 and Peltola 2007, two large studies that were both well conducted, but limited in their population demographics and follow-up data. Data from Peltola 2007 have been subject to systematic reviews investigating the effect of dexamethasone, and some methodological concerns were raised regarding the randomisation schedule (van de Beek 2010). As a result we have assigned this study an unclear risk of allocation bias.

Each study was undertaken in a very different environment and the population for each has its own particular issues. The HIV prevalence in Ajdukiewicz 2011 was $83.5 \%$ and the impact of this on mortality and other outcomes has not been measured and may be significant. Ajdukiewicz 2011 and Molyneux 2014 were conducted in a severely resource-limited environment in Malawi, with no access to advanced resuscitation or intensive care units (UNDP 2016). All other included studies were carried out in hospitals with intensive care units and paediatric specialist teams, which is not necessarily representative of most hospitals in low-income countries. This may introduce a degree of confounding, particularly regarding lower mortality rates in children.

Peltola 2007 was conducted at multiple sites and excluded participants who had received parenteral antibiotics but not oral antibiotics before the first dose of glycerol or dexamethasone or both glycerol and dexamethasone. The authors of Peltola 2007 did not include these data in the analysis, so it is unclear if prior antibiotic treatment had an effect on outcomes, particularly deafness.

The doses and duration of glycerol used varied across the included studies, introducing further inconsistencies among studies (see Table 2). We were unable to control for this effect in the analysis, which may have introduced further heterogeneity (Brouwer 2011; Saez-Llorens 2007). Prolonged use of osmotic agents, such as the four-day courses of glycerol used in Ajdukiewicz 2011, have been suggested to be harmful. Peltola 2007 and Sankar 2007 both used two-day courses due to this concern. However, most seizures and deaths in Ajdukiewicz 2011 occurred in the first two days, and therefore an association between mortality and glycerol duration is unlikely.
Different agents were used as placebo comparators in the studies. Ajdukiewicz 2011 used 50\% dextrose, Peltola 2007, Sankar 2007 and Molyneux 2014 used carboxymethylcellulose, and Kilpi 1995 did not use a placebo agent. It may be argued that the placebo agents used were not wholly inert and may exert an independent osmotic action. All trial authors designed control agents that had a similar taste and texture to glycerol for concealment purposes, and whether any of the substances used exerted an independent osmotic action is untested. However, the higher mortality reported by Ajdukiewicz 2011 in the glycerol group suggests that glycerol had an action beyond any osmotic effect exerted by the dextrose placebo, particularly as the glycerol was diluted in dextrose for some participants (Brouwer 2011).

The slight reduction in hearing loss observed suggests that glycerol may be acting to reduce oedema or improve cerebral blood flow in particular areas of the brain, either the nucleus or length of the vestibular-cochlear nerve (which is encased in a bony canal). There is some evidence to suggest that glycerol is required for bacterial metabolic pathways in the central nervous system (CNS) (Mahdi 2012). Genetic susceptibility to hearing loss following meningitis has been suggested and the presence of glycerol may attenuate the production of free radicals that may affect CNS damage leading to hearing loss (van Well 2012). We selected greater than $40 \mathrm{~dB}$ as the cut-off for hearing loss to capture all clinically significant deficits; the effect of glycerol on more severe hearing loss was not evaluated. Currently, there are no clear data showing the mechanistic effects of glycerol on either hearing or mortality in humans and more research is needed. Experimental animal work has shown no effect of glycerol in a bacterial meningitis model (Blaser 2010). The cause of increased mortality with glycerol in adults is unclear. Risk stratification of patients in that trial by disease severity showed that glycerol exerted harmful effects on those patients with low predicted risk of death on admission (Wall 2017). It is possible that increased mortality from glycerol in these patients with a more intact blood-brain barrier may relate to enhanced virulence of pneumococci in the CNS in the presence of glycerol (Mahdi 2012), or harmful effects of osmotic shift across the blood-brain barrier.

The use of dexamethasone did not have any impact on the outcomes studied when used with or without glycerol. Other larger reviews have found an impact of dexamethasone on the reduction of hearing loss in children with meningitis (van de Beek 2010). There were too few data available for analysis to inform a robust conclusion about the utility of dexamethasone for treatment of people with bacterial meningitis.

\section{Overall completeness and applicability of evidence}

This is an update of a Cochrane Review that examines the evidence for the use of osmotic therapies in acute bacterial meningitis. To date, the evidence is incomplete and unequivocal findings for the use of glycerol for people with meningitis could not be derived. Data from further studies are required, particularly in children, to assess the impact of glycerol on meningitis-induced hearing loss. There is no evidence testing any other osmotic therapy apart from glycerol for meningitis: data from clinical studies are required. The highquality evidence from Ajdukiewicz 2011 demonstrates harm from glycerol in adults with bacterial meningitis in Malawi and no further testing or clinical use of glycerol in adults is currently warranted. 


\section{Quality of the evidence}

We assessed the quality of evidence provided by this review using the GRADE methods (Summary of findings for the main comparison). We generally assessed the evidence as low- or very low-quality, which indicates that further research is very likely to change the estimates of effect.

The main reasons for downgrading evidence quality were the small size of the trials, the low numbers of events and the substantial differences between locations, sizes and participant populations studied in the included studies. Much larger trials would be necessary to prove or exclude significant benefits or harms.

We also downgraded the evidence quality for mortality and seizures due to inconsistency. The only trial in adults was stopped early due to small but statistically significant harm (Ajdukiewicz 2011), while four trials in children did not demonstrate statistically significant effects.

\section{Potential biases in the review process}

Dr Katherine Ajdukiewicz is an author of this Cochrane Review and was the principal investigator for one of the included studies. To minimise bias she did not extract any data from her study to include in the analysis or perform any of the analysis.

\section{Agreements and disagreements with other studies or reviews}

There are no current systematic reviews examining glycerol or other osmotic agents for use in acute bacterial meningitis.

\section{AUTHORS' CONCLUSIONS}

\section{Implications for practice}

There is no evidence to support the use of glycerol as adjunctive treatment for acute bacterial meningitis. Glycerol may have a small beneficial effect on reducing deafness in surviving children but further data are needed. Overall, the evidence quality is low.

\section{Implications for research}

Trials testing other osmotic interventions in acute bacterial meningitis may be considered, particularly in children.

\section{ACKNOWLEDGEMENTS}

We wish to thank Sarah Thorning for assistance with the search strategy and support and Dr David Sinclair for his help synthesising the 'Summary of findings' table. We thank the following people for commenting on the draft protocol: Anne Lyddiatt, Teenah Handiside, Amit Kumar, Max Bulsara and Diederik van de Beek. We also thank the following people for commenting on the original review: Sylvia Beamon, Kameshwar Prasad, Matthijs Brouwer, Teresa Neeman and Diederik van de Beek.

Paul Garner and David Sinclair received support from the Effective Health Care Research Consortium, which is funded by UK aid from the UK Government Department for International Development (grant number 5242). 


\section{R E F E R E N C E S}

\section{References to studies included in this review}

Ajdukiewicz 2011 \{published data only\}

Ajdukiewicz KM. Glycerol adjuvant therapy in adult bacterial meningitis in Malawi [MD thesis]. Liverpool (UK): University of Liverpool, 2012.

* Ajdukiewicz KM, Cartwright KE, Scarborough M, Mwambene JB, Goodson P, Molyneux ME, et al. Glycerol adjuvant therapy in adults with bacterial meningitis in a high HIV seroprevalence setting in Malawi: a double-blind, randomised controlled trial. Lancet Infectious Diseases 2011;11(4):293-300.

\section{Kilpi 1995 \{published data only\}}

Kilpi T, Peltola H, Jauhiainen T, Kallio MJ. Oral glycerol and intravenous dexamethasone in preventing neurologic and audiologic sequelae of childhood bacterial meningitis. The Finnish Study Group. Pediatric Infectious Disease Journal 1995;14(4):270-8.

\section{Molyneux 2014 \{published data only\}}

Molyneux EM, Kawaza K, Phiri A, Chimalizeni Y, Mankhambo L, Schwalbe E, et al. Glycerol and acetaminophen as adjuvant therapy did not affect the outcome of bacterial meningitis in Malawian children. Pediatric Infectious Disease Journal 2014;33(2):214-6.

\section{Peltola 2007 \{published data only\}}

Peltola H, Roine I, Fernandez J, Gonzlez MA, Zavala I, Gonzalez A, et al. Hearing impairment in childhood bacterial meningitis is little relieved by dexamethasone or glycerol. Paediatrics 2010;125(1):e1-8.

* Peltola H, Roine I, Fernandez J, Zavala I, Ayala SG, Mata AG, et al. Adjuvant glycerol and/or dexamethasone to improve the outcomes of childhood bacterial meningitis: a prospective, randomized, double-blind, placebo-controlled trial. Clinical Infectious Diseases 2007;45(10):1277-86.

Sankar 2007 \{published data only\}

* Sankar J, Singhi P, Bansal A, Ray P, Singhi S. Role of dexamethasone and oral glycerol in reducing hearing and neurological sequelae in children with bacterial meningitis. Indian Pediatrics 2007;44(9):649-56.

Singhi S, Järvinen A, Peltola H. Increase in serum osmolality is possible mechanism for the beneficial effects of glycerol in childhood bacterial meningitis. Pediatric Infectious Diseases Journal 2008;27(10):892-6.

\section{References to studies excluded from this review}

Almirante 1995 \{published data only\}

Almirante B, Cortés E, Pigrau C, Gasser I, del Valle O, Campos L, et al. Therapy and outcome of pneumococcal meningitis in adults. A recent series of 70 episodes. Medicina Clinica 1995;105(18):681-6.
CTRI/2015/04/005668 \{published data only\}

CTRI/2015/04/005668. Oral glycerol in newborn brain infections [Randomized comparison of oral glycerol and standard treatment versus standard treatment alone in management of neonatal bacterial meningitis]. ctri.nic.in/Clinicaltrials/ pmaindet2.php?trialid=11180 (first received 7 April 2015).

Glimåker 2014 \{published data only\}

Glimåker M, Johansson B, Halldorsdottir H, Wanecek M, ElmiTerander A, Ghatan PH, et al. Neuro-intensive treatment targeting intracranial hypertension improves outcome in severe bacterial meningitis: an intervention-control study. PloS One 2014;9(3):e91976.

\section{Herson 1977 \{published data only\}}

Herson VC, Todd JK. Prediction of morbidity in Hemophilus influenzae meningitis. Pediatrics 1977;59(1):35-9.

\section{Kumar 2014 \{published data only\}}

CTRI/2012/05/002650. The effects of cerebral perfusion pressure and intracranial pressure targeted therapy in children with raised intracranial pressure and acute central nervous system infections [A pilot study to compare the outcome of CPP targeted therapy versus ICP targeted therapy in children with acute meningitis]. ctri.nic.in/Clinicaltrials/pmaindet2.php? trialid=4595 (first received 14 May 2012)

Kumar R, Singhi S, Singhi P, Jayashree M, Bansal A, Bhatti A. Randomized controlled trial comparing cerebral perfusion pressure-targeted therapy versus intracranial pressure-targeted therapy for raised intracranial pressure due to acute CNS infections in children. Critical Care Medicine 2014;42(8):1775-87.

\section{Molyneux 2015 \{published data only\}}

Molyneux E, Njiram'madzi J. Prevention and treatment of bacterial meningitis in resource poor settings. Pediatric Infectious Disease Journal 2015;34(4):441-3.

\section{Pecco 1991 \{published data only\}}

Pecco P, Pavesio D, Peisino MG. Rational basis of modern therapy of bacterial meningitis. Review of the literature and our clinical experience of 122 pediatric cases. Panminerva Medica 1991;33(4):185-90.

\section{Pelegrin 2012 \{published data only\}}

Pelegrin I, Verdaguer R, Ariza J, Viladrich PF, Cabellos C. Effect of adjuvant therapy in pneumococcal meningitis: seizures and mortality. Clinical Microbiology and Infection 2012;19(Suppl):834.

\section{Peltola 2013 \{published data only\}}

Peltola H, Leib SL. Performance of adjunctive therapy in bacterial meningitis depends on circumstances. Pediatric Infectious Disease Journal 2013;32(12):1381-2.

\section{Singhi 2004 \{published data only\}}

Singhi S, Khetarpal R, Baranwal AK, Singhi PD. Intensive care needs of children with acute bacterial meningitis: a 
developing country perspective. Annals of Tropical Paediatrics 2004;24(2):133-40.

\section{Singhi 2007 \{published data only\}}

Singhi S, Singhi P. Glycerol and dexamethasone in bacterial meningitis in low-income countries: response to the editorial commentary. Clinical Infectious Diseases 2007;47(5):732-3.

\section{Urciuoli 1963 \{published data only\}}

Urciuoli R. A new osmotic drug: hypertonic solution of mannitol. Advantages as compared with urea. Use in the treatment of aseptic serous meningitis and postoperative cerebrospinal fluid fistulas. Gazzetta Medica Italiana 1963;122:234-6.

Vaziri 2016 \{published data only\}

Vaziri S, Mansouri F, Sayad B, Ghadiri K, Torkashvand E, Rezaei M, et al. Meta-analysis of studies comparing adjuvant dexamethasone to glycerol to improve clinical outcome of bacterial meningitis. Journal of Research in Medical Sciences 2016;21(2):8.

\section{Additional references}

\section{Atkins 2004}

Atkins D, Best D, Briss PA, Eccles M, Falck-Ytter Y, Flottorp S, et al. GRADE Working Group. Grading quality of evidence and strength of recommendations. BMJ 2004;328(7454):1490.

\section{Bereczki 2007}

Bereczki D, Liu M, Fernandes do Prado G, Fekete I. Mannitol for acute stroke. Cochrane Database of Systematic Reviews 2007, Issue 3. [DOI: 10.1002/14651858.CD001153.pub2]

\section{Blaser 2010}

Blaser C, Klein M, Grandgirard D, Wittwer M, Peltola H, Weigand $\mathrm{M}$, et al. Adjuvant glycerol is not beneficial in experimental pneumococcal meningitis. BMC Infectious Diseases 2010;10:84.

\section{Brouwer 2011}

Brouwer M, van de Beek D. Glycerol in bacterial meningitis: one strike and out?. Lancet Infectious Diseases 2011;11(4):257-8.

\section{Brouwer 2015}

Brouwer MC, Mclntyre P, de Gans J, Prasad K, van de Beek D. Corticosteroids for acute bacterial meningitis. Cochrane Database of Systematic Reviews 2015, Issue 9. [DOI: 10.1002/14651858.CD004405.pub5]

\section{BTF 2000}

Brain Trauma Foundation. The American Association of Neurological Surgeons. The Joint Section on Neurotrauma and Critical Care. Initial management. Journal of Neurotrauma 2000;17(6-7):463-9.

\section{Choi 2005}

Choi CW, Hwang JH, Chang JS, Park WS, Kim BI, Choi JH, et al. Effects of hypertonic (7\%) saline on brain injury in experimental Escherichia coli meningitis. Journal of Korean Medical Science 2005;20(5):870-6.

\section{de Gans 2002}

de Gans J, van de Beek D. Dexamethasone in adults with bacterial meningitis. New England Journal of Medicine 2002;347(20):1549-56

\section{Domingo 2009}

Domingo P, Suarez-Lozano I, Torres F, Pomar V, Ribera E, Galindo MJ, et al. Bacterial meningitis in HIV-1-infected patients in the era of highly active antiretroviral therapy. Journal of Acquired Immune Deficiency Syndromes 2009;51(5):582-7.

\section{GRADEpro GDT 2014 [Computer program]}

GRADE Working Group, McMaster University. GRADEpro GDT. Version accessed prior to 6 September 2017. Hamilton (ON): GRADE Working Group, McMaster University, 2014.

\section{Harnden 2006}

Harnden A, Ninis N, Thompson M, Perera R, Levin M, Mant D, et al. Parenteral penicillin for children with meningococcal disease before hospital admission: case-control study. BMJ (Clinical Research ed.) 2006;332(7553):1295-8.

\section{Higgins 2011}

Higgins JP, Green S, editor(s). Cochrane Handbook for Systematic Reviews of Interventions Version 5.1.0 (updated March 2011). The Cochrane Collaboration, 2011. Available from handbook.cochrane.org.

\section{Ichai 2009}

Ichai C, Armando G, Orban JC, Berthier F, Rami L, Samat-Long C, et al. Sodium lactate versus mannitol in the treatment of intracranial hypertensive episodes in severe traumatic braininjured patients. Intensive Care Medicine 2009;35(3):471-9.

\section{Lefebvre 2011}

Lefebvre C, Manheimer E, Glanville J. Chapter 6: Searching for studies. Cochrane Handbook for Systematic Reviews of Interventions. Version 5.1.0 (updated March 2011). The Cochrane Collaboration. Available from www.handbook.cochrane.org 2011.

\section{Maconochie 2016}

Maconochie IK, Baumer JH. Fluid therapy for acute bacterial meningitis. Cochrane Database of Systematic Reviews 2016, Issue 11. [DOI: 10.1002/14651858.CD004786.pub5]

\section{Mahdi 2012}

Mahdi LK, Wang H, Van der Hoek M, Paton JC, Ogunniyi AD. Identification of a novel pneumococcal vaccine antigen preferentially expressed during meningitis in mice. Journal of Clinical Investigation 2012;122(6):2208-20.

\section{Mathew 1972}

Mathew NT, Rivera VM, Meyer JS, Charney JZ, Hartmann A. Double-blind evaluation of glycerol therapy in acute cerebral infarction. Lancet 1972;2(7791):1327-9.

\section{McCormick 2012}

McCormick DW, Wilson ML, Mankhambo L, Phiri A, Chimalizeni Y, Kawaza K, et al. Risk factors for death and severe sequelae 
in Malawian children with bacterial meningitis, 1997-2010. Pediatric Infectious Diseases Journal 2012;32(2):e54-61.

\section{Meyer 1972}

Meyer JS, Teraura T, Marx P, Hashi K, Sakamoto K. Brain swelling due to experimental cerebral infarction. Changes in vasomotor capacitance and effects of intravenous glycerol. Brain 1972;95(4):833-52.

\section{Molyneux 2002}

Molyneux EM, Walsh AL, Forsyth H, Tembo M, Mwenechanya J, Kayira K, et al. Dexamethasone treatment in childhood bacterial meningitis in Malawi: a randomised controlled trial. Lancet 2002;360(9328):211-8.

\section{Molyneux 2006}

Molyneux E, Riordan FA, Walsh A. Acute bacterial meningitis in children presenting to the Royal Liverpool Children's Hospital, Liverpool, UK and the Queen Elizabeth Central Hospital in Blantyre, Malawi: a world of difference. Annals of Tropical Paediatrics 2006;26(1):29-37.

\section{Namutangula 2007}

Namutangula B, Ndeezi G, Byarugaba JS, Tumwine JK. Mannitol as adjunct therapy for childhood cerebral malaria in Uganda: a randomized clinical trial. Malaria Journal 2007;6:138.

\section{Nguyen 2007}

Nguyen TH, Tran TH, Thwaites G, Ly VC, Dinh XS, Ho Dang TN, et al. Dexamethasone in Vietnamese adolescents and adults with bacterial meningitis. New England Journal of Medicine 2007;357(24):2431-40.

\section{Okoromah 2011}

Okoromah CAN, Afolabi BB, Wall ECB. Mannitol and other osmotic diuretics as adjuncts for treating cerebral malaria. Cochrane Database of Systematic Reviews 2011, Issue 4. [DOI: 10.1002/14651858.CD004615.pub3]

\section{Pelkonen 2009}

Pelkonen T, Roine I, Monteiro L, Correia M, Pitkaranta A, Bernardino $L$, et al. Risk factors for death and severe neurological sequelae in childhood bacterial meningitis in subSaharan Africa. Clinical Infectious Diseases 2009;48(8):1107-10.

\section{Peltola 2009}

Peltola H, Roine I. Improving the outcomes in children with bacterial meningitis. Current Opinion in Infectious Diseases 2009;22(3):250-5.

\section{Review Manager 2014 [Computer program]}

Nordic Cochrane Centre, The Cochrane Collaboration. Review Manager 5 (RevMan). Version 5.3. Copenhagen: Nordic Cochrane Centre, The Cochrane Collaboration, 2014.

\section{Righetti 2004}

Righetti E, Celani MG, Cantisani TA, Sterzi R, Boysen G, Ricci S. Glycerol for acute stroke. Cochrane Database of Systematic Reviews 2004, Issue 2. [DOI: 10.1002/14651858.CD000096.pub2]

\section{Roine 2009}

Roine I, Saukkoriipi A, Leinonen M, Peltola H. Microbial genome count in cerebrospinal fluid compared with clinical characteristics in pneumococcal and Haemophilus influenzae type B meningitis in children. Diagnostic Microbiology Infectious Diseases 2009;63(1):16-23.

\section{Saez-Llorens 2007}

Saez-Llorens X, McCracken GH Jr. Glycerol and bacterial meningitis. Clinical Infectious Diseases 2007;45(10):1287-9.

\section{Scarborough 2007}

Scarborough M, Gordon SB, Whitty CJ, French N, Njalale Y, Chitani A, et al. Corticosteroids for bacterial meningitis in adults in sub-Saharan Africa. New England Journal of Medicine 2007;357(24):2441-50.

\section{Schmidt 1998}

Schmidt H, Stuertz K, Chen V, Stringaris AK, Bruck W, Nau R. Glycerol does not reduce neuronal damage in experimental Streptococcus pneumoniae meningitis in rabbits. Inflammopharmacology 1998;6(1):19-26.

\section{Schwarz 2002}

Schwarz S, Georgiadis D, Aschoff A, Schwab S. Effects of hypertonic $(10 \%)$ saline in patients with raised intracranial pressure after stroke. Stroke 2002;33(1):136-40.

\section{Singhi 2008}

Singhi S, Järvinen A, Peltola H. Increase in serum osmolality is possible mechanism for the beneficial effects of glycerol in childhood bacterial meningitis. Pediatric Infectious Diseases Journal 2008;27(10):892-6.

\section{Stoll 1998}

Stoll J, Hagen M, Bartylla T, Weber K, Jost M, Treib V. Changes of cerebral perfusion after osmotherapy in acute cerebral edema assessed with perfusion weighted MRI. Neurological Research 1998;20(6):474-8

\section{Sudarsanam 2017}

Sudarsanam TD, Rupali P, Tharyan P, Abraham OC, Thomas K. Pre-admission antibiotics for suspected cases of meningococcal disease. Cochrane Database of Systematic Reviews 2017, Issue 6. [DOI: 10.1002/14651858.CD005437.pub4]

\section{UNDP 2016}

United Nations Development Programme. Human Development Report. hdr.undp.org/en/reports/global/hdr2009/ (accessed prior to 13 September 2017).

\section{van de Beek 2009}

van de Beek D. Corticosteroids for acute adult bacterial meningitis. Medical Maladies Infectieuse 2009;39(7-8):531-8.

\section{van de Beek 2010}

van de Beek D, Farrar JJ, de Gans J, Mai NT, Molyneux EM, Peltola $\mathrm{H}$, et al. Adjunctive dexamethasone in bacterial meningitis: a meta-analysis of individual patient data. Lancet Neurology 2010;9(3):254-63. 


\section{van Well 2012}

van Well GT, Sanders MS, Ouburg S, van Furth AM, Morré SA. Polymorphisms in toll-like receptors 2, 4, and 9 are highly associated with hearing loss in survivors of bacterial meningitis. PLoS One 2012;7(5):e35837.

\section{Wakai 2013}

Wakai A, McCabe A, Roberts I, Schierhout G. Mannitol for acute traumatic brain injury. Cochrane Database of Systematic Reviews 2013, Issue 8. [DOI: 10.1002/14651858.CD001049.pub5]

\section{Wall 2017}

Wall EC, Mukaka M, Scarborough M, Ajdukiewicz KMA, Cartwright KE, Nyirenda M, et al. Prediction of outcome from adult bacterial meningitis in a high-HIV-seroprevalence, resource-poor setting using the Malawi Adult Meningitis Score (MAMS). Clinical Infectious Diseases 2017;64(4):413-9.

\section{Yu 1992}

Yu YL, Kumana CR, Lauder IJ, Cheung YK, Chan FL, Kou M, et al. Treatment of acute cerebral hemorrhage with intravenous glycerol. A double-blind, placebo-controlled, randomized trial. Stroke 1992;23(7):967-71.

\section{CHARACTERISTICS OF STUDIES}

Characteristics of included studies [ordered by study ID]

\section{Yu 1993}

Yu YL, Kumana CR, Lauder IJ, Cheung YK, Chan FL, Kou M, et al. Treatment of acute cortical infarct with intravenous glycerol. A double-blind, placebo-controlled randomized trial. Stroke 1993;24(8):1119-24.

\section{References to other published versions of this review Wall 2010}

Wall ECB, Ajdukiewicz KMB, Heyderman RS, Garner P. Osmotic therapies as adjuncts to antibiotics for acute bacterial meningitis. Cochrane Database of Systematic Reviews 2010, Issue 11. [DOI: 10.1002/14651858.CD008806]

\section{Wall 2013}

Wall ECB, Ajdukiewicz KMB, Heyderman RS, Garner P. Osmotic therapies added to antibiotics for acute bacterial meningitis. Cochrane Database of Systematic Reviews 2013, Issue 3. [DOI: 10.1002/14651858.CD008806.pub2]

* Indicates the major publication for the study

Ajdukiewicz 2011

\begin{tabular}{ll}
\hline Methods & Randomised controlled trial \\
\hline Participants & $\begin{array}{l}\text { Adults with bacterial meningitis (clinical suspicion of meningitis plus CSF evidence of infection: > 100 } \\
\text { white cells } / \mathrm{mm}^{3}, \text { predominately neutrophils, a positive gram stain or cloudy CSF) }\end{array}$ \\
\hline Interventions & Oral glycerol $75 \mathrm{mg}$ in $135 \mathrm{~mL}$ \\
& Oral glucose $50 \%$ solution $135 \mathrm{~mL}$ \\
\hline Outcomes & Primary outcome: mortality \\
& Secondary outcomes: epilepsy, deafness, residual neurological deficit at day 40 \\
\hline Notes & Source of funding: the Meningitis Research Foundation \\
Placebo is potentially not completely inactive and $50 \%$ glucose may exert a neurological effect in \\
meningitis
\end{tabular}

\section{Risk of bias}

\begin{tabular}{lll}
\hline Bias & Authors' judgement & Support for judgement \\
\hline $\begin{array}{l}\text { Random sequence genera- } \\
\text { tion (selection bias) }\end{array}$ & Low risk & $\begin{array}{l}\text { "A randomisation number list in blocks of } 12 \text { was produced by an independent } \\
\text { statistician using Stata version 9.0" }\end{array}$ \\
\hline $\begin{array}{l}\text { Allocation concealment } \\
\text { (selection bias) }\end{array}$ & Low risk & $\begin{array}{l}\text { "Numbers and allocation were placed into sealed envelopes. Envelopes were } \\
\text { opened sequentially by an independent person not involved in the clinical } \\
\text { care or assessment of trial participants" }\end{array}$ \\
\hline
\end{tabular}

Blinding (performance
bias and detection bias)

Osmotic therapies added to antibiotics for acute bacterial meningitis (Review) 
Ajdukiewicz 2011 (Continued)

All outcomes

Incomplete outcome data Low risk Intention-to-treat analysis; all participants included in the analysis
(attrition bias)

(attrition bias)

All outcomes

\begin{tabular}{lll}
\hline $\begin{array}{l}\text { Selective reporting (re- } \\
\text { porting bias) }\end{array}$ & Low risk & None apparent \\
\hline Other bias & Low risk & No other biases apparent \\
\hline
\end{tabular}

\section{Kilpi 1995}

\begin{tabular}{ll}
\hline Methods & Randomised controlled trial with 4 arms \\
\hline Participants & $\begin{array}{l}\text { Children from } 3 \text { months to } 15 \text { years of age with bacterial meningitis (CSF culture positive; CSF leuco- } \\
\text { cytes }>100 / \mathrm{mm}^{2} ; \text { positive blood culture in a child with signs and symptoms of bacterial meningitis) }\end{array}$ \\
\hline Interventions & $\begin{array}{l}\text { Glycerol } 4.5 \mathrm{~g} / \mathrm{kg} \text { to a maximum } 180 \mathrm{~g} / \text { day divided into } 3 \text { doses } / 24 \text { hours. Increased by } 50 \% \text { for dose } 1 \\
\text { and decreased by } 50 \% \text { for dose } 2 . \text { No details of placebo given. Treatment given for } 3 \text { days }\end{array}$ \\
& $\begin{array}{l}\text { Dexamethasone } 1.5 \mathrm{mg} / \mathrm{kg} \text { once daily IV divided into } 3 \text { doses/24 hours. 50\% dose adjustments as per } \\
\text { glycerol also used. Treatment given for } 3 \text { days }\end{array}$ \\
& $\begin{array}{l}\text { groups used, glycerol, glycerol + dexamethasone, dexamethasone and "neither" } \\
\text { Outcomes }\end{array}$ \\
Primary outcome: mortality \\
Secondary outcomes: epilepsy, deafness, residual neurological deficit
\end{tabular}

\section{Risk of bias}

\begin{tabular}{|c|c|c|}
\hline Bias & Authors' judgement & Support for judgement \\
\hline $\begin{array}{l}\text { Random sequence genera- } \\
\text { tion (selection bias) }\end{array}$ & Low risk & $\begin{array}{l}\text { "A computer generated list of random therapy assignments was kept at the } \\
\text { children's hospital" }\end{array}$ \\
\hline \multirow[t]{2}{*}{$\begin{array}{l}\text { Allocation concealment } \\
\text { (selection bias) }\end{array}$} & Low risk & $\begin{array}{l}\text { "The next adjunctive treatment regimen was obtainable by telephone } 24 \text { hours } \\
\text { a day" }\end{array}$ \\
\hline & & $\begin{array}{l}\text { It was not clear if this person giving the assignments was part of the study } \\
\text { team or independent }\end{array}$ \\
\hline $\begin{array}{l}\text { Blinding (performance } \\
\text { bias and detection bias) } \\
\text { All outcomes }\end{array}$ & High risk & No details of blinding were given, so we assumed the study was unblinded \\
\hline $\begin{array}{l}\text { Incomplete outcome data } \\
\text { (attrition bias) } \\
\text { All outcomes }\end{array}$ & High risk & $\begin{array}{l}134 \text { children enrolled, } 12 \text { excluded, } 122 \text { in the final series but only } 120 \\
\text { analysed. Details of the missing data were not present in the text }\end{array}$ \\
\hline
\end{tabular}


Kilpi 1995 (Continued)

$\begin{array}{ll}\begin{array}{l}\text { Selective reporting (re- High risk } \\ \text { porting bias) }\end{array} & \begin{array}{l}\text { No details of the missing data given, so it is not clear if selective cases are pre- } \\ \text { sented }\end{array}\end{array}$

porting bias)

Other bias

Unclear risk

Groups not completely matched: more females in the dexamethasone group and increased meningitis due to $S$ pneumoniae in the control group

Molyneux 2014

\begin{tabular}{ll}
\hline Methods & Randomised controlled trial with 4 arms \\
\hline Participants & $\begin{array}{l}\text { Children aged } 2 \text { months or older with bacterial meningitis (CSF culture positive; CSF leucocytes } \geq 100 / \\
\mathrm{mm}^{2} \text { with positive blood culture; CSF } \geq 100 \text { leukocytes with signs and symptoms of bacterial meningi- } \\
\text { tis) }\end{array}$ \\
\hline
\end{tabular}

\begin{tabular}{|c|c|}
\hline \multirow[t]{7}{*}{ Interventions } & 1. Glycerol + paracetamol \\
\hline & 2. Glycerol \\
\hline & 3. Paracetamol \\
\hline & 4. Placebo \\
\hline & $\begin{array}{l}\text { All placebo-controlled: carboxymethylcellulose (placebo for glycerol) and cocoa butter base supposito- } \\
\text { ry (placebo for paracetamol) }\end{array}$ \\
\hline & Doses: glycerol $6 \mathrm{~g} / \mathrm{kg} /$ day in 4 daily doses (maximum $2.5 \mathrm{mg} /$ dose) for 2 days \\
\hline & Acetaminophen rectal suppository $35 \mathrm{mg} / \mathrm{kg}$ first dose followed by $20 \mathrm{mg} / \mathrm{kg}$ 6-hourly for 42 hours \\
\hline \multirow[t]{6}{*}{ Outcomes } & Primary outcome: \\
\hline & - Survival to 6 months post discharge with no sequelae \\
\hline & Secondary outcomes: \\
\hline & $\begin{array}{l}\text { - Sequelae that affect daily life (e.g. hemiplegia, deafness, blindness, seizures, global developmental } \\
\text { delay) at } 6 \text { months }\end{array}$ \\
\hline & - Severe incapacitating sequelae \\
\hline & - Death \\
\hline \multirow[t]{2}{*}{ Notes } & Source of funding: the Academy of Finland \\
\hline & $\begin{array}{l}\text { In the trial registration from 2008, the primary outcomes were: death, severe neurological sequelae and } \\
\text { hearing loss; secondary outcomes were: audiological or neurological sequelae }\end{array}$ \\
\hline
\end{tabular}

\section{Risk of bias}

\begin{tabular}{lll}
\hline Bias & Authors' judgement & Support for judgement \\
\hline $\begin{array}{l}\text { Random sequence genera- } \\
\text { tion (selection bias) }\end{array}$ & Low risk & "...randomisation was computer generated in permuted blocks of 12" \\
\hline $\begin{array}{l}\text { Allocation concealment } \\
\text { (selection bias) }\end{array}$ & Unclear risk & No information \\
\hline
\end{tabular}

Blinding (performance Low risk No report in trial. Email from author that the trial was "double blind" bias and detection bias) All outcomes 
Molyneux 2014 (Continued)

Incomplete outcome data Low risk Intention-to-treat analysis; all participants included in the analysis (attrition bias)

All outcomes

\begin{tabular}{lll}
\hline $\begin{array}{l}\text { Selective reporting (re- } \\
\text { porting bias) }\end{array}$ & Unclear risk & None apparent. Some differences between trial report and trial registration \\
\hline Other bias & Unclear risk & $\begin{array}{l}\text { No detailed baseline characteristics: "baseline data for the } 4 \text { groups were simi- } \\
\text { lar except more children had received antibiotics in the paracetamol + glycerol } \\
\text { group" }\end{array}$ \\
\hline
\end{tabular}

Peltola 2007

\begin{tabular}{ll}
\hline Methods & Randomised controlled trial with 4 arms, multicentre in South America \\
\hline Participants & $\begin{array}{l}\text { Children aged } 2 \text { months to } 16 \text { years with bacterial meningitis (CSF culture positive, "characteristic CSF } \\
\text { findings" with a positive blood culture or CSF positive with latex antigen test; symptoms and signs of } \\
\text { bacterial meningitis with at least } 3 \text { of the following: CSF white cell count }>1000 \text { cells } / \mathrm{mm}^{3}, \text { CSF glucose } \\
<40 \mathrm{mg} / \mathrm{dL}, \mathrm{CSF} \text { protein }>40 \mathrm{mg} / \mathrm{dL} \text {, blood white cell count }>15,000 \text { cells } / \mathrm{mm}^{3}\end{array}$ \\
\hline Interventions & $\begin{array}{l}\text { Glycerol } 1.5 \mathrm{~g} / \mathrm{kg} \text { in an } 85 \% \text { solution divided into } 3 \text { doses/24 hours. Treatment given for } 2 \text { days } \\
\text { Placebo: saline plus carboxy methylcellulose. Doses and volumes of placebo not given in the paper }\end{array}$ \\
& Dexamethasone $0.15 \mathrm{mg} / \mathrm{kg}$ once daily IV divided into 3 doses/24 hours. Treatment given for 2 days \\
& $\begin{array}{l}\text { 4 groups: glycerol + placebo, glycerol + dexamethasone, dexamethasone + placebo and placebo + } \\
\text { placebo }\end{array}$ \\
\hline Outcomes & $\begin{array}{l}\text { Primary mortality. No secondary mortality at the end of follow-up given } \\
\text { Secondary outcomes: epilepsy, deafness and residual neurological deficit }\end{array}$ \\
\hline Notes & $\begin{array}{l}\text { Source of funding: GlaxoSmithKline, Alfred Kordelin, Päivikki and Sakari Sohlberg, and Sigfrid Jusélius } \\
\text { ly donated ceftriaxone. }\end{array}$ \\
\hline
\end{tabular}

\section{Risk of bias}

\begin{tabular}{lll}
\hline Bias & Authors' judgement & Support for judgement \\
\hline $\begin{array}{l}\text { Random sequence genera- } \\
\text { tion (selection bias) }\end{array}$ & Unclear risk & "Stratified block randomisation took place in blocks of 20" \\
\hline $\begin{array}{l}\text { Allocation concealment } \\
\text { (selection bias) }\end{array}$ & Low risk & $\begin{array}{l}\text { "All treatment kits were packaged according to the randomisation lists in San- } \\
\text { tiago, Chile. Saline and carboxymethylcellulose were the placebo preparations } \\
\text { for dexamethasone and glycerol, respectively. The agents were provided in } \\
\text { identical ampoules or bottles and were labelled only with a study code" }\end{array}$
\end{tabular}

\begin{tabular}{ll}
$\begin{array}{l}\text { Blinding (performance } \\
\text { bias and detection bias) }\end{array}$ & Low risk \\
$\begin{array}{ll}\text { All outcomes } & \text { "All treatment kits were packaged according to the randomisation lists in San- } \\
& \text { tiago, Chile. Saline and carboxymethylcellulose were the placebo preparations } \\
& \text { for dexamethasone and glycerol, respectively. The agents were provided in } \\
\text { identical ampoules or bottles and were labelled only with a study code" }\end{array}$ \\
\hline
\end{tabular}

$\begin{aligned} & \text { Incomplete outcome data } \\ & \text { (attrition bias) }\end{aligned}$
Low risk None identified


Peltola 2007 (Continued)

All outcomes

\begin{tabular}{lll}
\hline $\begin{array}{l}\text { Selective reporting (re- } \\
\text { porting bias) }\end{array}$ & Low risk & No missing data identified \\
\hline Other bias & Unclear risk & $\begin{array}{l}\text { Drugs were supplied by GlaxoSmithKline (GSK) and Farmacia Ahumada. GSK } \\
\text { partially funded the study }\end{array}$ \\
\hline
\end{tabular}

\section{Sankar 2007}

\begin{tabular}{ll}
\hline Methods & Randomised controlled trial. Single centre \\
\hline Participants & $\begin{array}{l}\text { Children aged } 2 \text { months to } 12 \text { years with bacterial meningitis (positive CSF culture or CSF latex agglu- } \\
\text { tination positive, or CSF cytology with a suggestive biochemical profile with fever and signs of CNS in- } \\
\text { volvement) }\end{array}$ \\
\hline Interventions & $\begin{array}{l}\text { Glycerol } 1.5 \mathrm{~g} / \mathrm{kg} \text { IV or orally 6-hourly. Placebo carboxymethyl cellulose } 2 \% \text { solution IV. Total dose of } \\
\text { placebo not given just documented "matched". Dexamethasone } 0.15 \mathrm{mg} / \mathrm{kg} 6 \text {-hourly. Duration of treat- } \\
\text { ment not reported }\end{array}$ \\
\hline Outcomes & Primary mortality. No secondary mortality at the end of follow-up given \\
\hline Secondary outcomes: epilepsy, deafness and residual neurological deficit
\end{tabular}

\section{Risk of bias}

\begin{tabular}{|c|c|c|}
\hline Bias & Authors' judgement & Support for judgement \\
\hline $\begin{array}{l}\text { Random sequence genera- } \\
\text { tion (selection bias) }\end{array}$ & Low risk & Randomisation list prepared with a simple random numbers table \\
\hline $\begin{array}{l}\text { Allocation concealment } \\
\text { (selection bias) }\end{array}$ & Low risk & Serially numbered, sealed packets prepared, kept readily available \\
\hline $\begin{array}{l}\text { Blinding (performance } \\
\text { bias and detection bias) } \\
\text { All outcomes }\end{array}$ & Low risk & $\begin{array}{l}\text { Clinicians and participants blinded. It was not clear from the text if the investi- } \\
\text { gators were fully blinded but the packets were prepared by a separate person } \\
\text { from the investigating team }\end{array}$ \\
\hline $\begin{array}{l}\text { Incomplete outcome data } \\
\text { (attrition bias) } \\
\text { All outcomes }\end{array}$ & Low risk & Outcome data were complete \\
\hline $\begin{array}{l}\text { Selective reporting (re- } \\
\text { porting bias) }\end{array}$ & Unclear risk & $\begin{array}{l}\text { No data were reported for important outcomes: adverse events and time for } \\
\text { stopping treatment }\end{array}$ \\
\hline Other bias & Low risk & No other biases apparent \\
\hline
\end{tabular}

CNS - central nervous system; CSF - cerebrospinal fluid; IV - intravenous 
Characteristics of excluded studies [ordered by study ID]

\begin{tabular}{|c|c|}
\hline Study & Reason for exclusion \\
\hline Almirante 1995 & $\begin{array}{l}\text { Case series of mannitol used for bacterial meningitis. No randomisation or placebo use document- } \\
\text { ed }\end{array}$ \\
\hline CTRI/2015/04/005668 & $\begin{array}{l}\text { RCT of newborns with bacterial meningitis receiving oral glycerol versus standard treatment. Eligi- } \\
\text { ble for inclusion, but the trial was suspended. This was confirmed by the trialists }\end{array}$ \\
\hline Glimåker 2014 & $\begin{array}{l}\text { Not a RCT: retrospectively identified controls. Osmotherapy (hypertonic saline) was one of the in- } \\
\text { terventions }\end{array}$ \\
\hline Herson 1977 & Not a RCT. Glycerol use discussed \\
\hline Kumar 2014 & $\begin{array}{l}\text { Open-label RCT of children with raised intracranial pressure due to acute CNS infections, including } \\
\text { meningitis receiving fluid and vasoactive therapy to maintain cerebral perfusion pressure above } 60 \\
\mathrm{~mm} \text { Hg versus hyperventilation and osmotherapy to maintain intercranial pressure below } 20 \mathrm{~mm} \\
\mathrm{Hg}\end{array}$ \\
\hline Molyneux 2015 & Review article. Glycerol use discussed \\
\hline Pecco 1991 & Literature review and documented personal experience of the use of mannitol in meningitis \\
\hline Pelegrin 2012 & $\begin{array}{l}\text { Retrospective cohort study examining patients with bacterial meningitis } 1987 \text { to } 2009 \text { who were } \\
\text { treated with dexamethasone, mannitol and phenytoin. No data were collected prospectively and } \\
\text { participants were not randomised to receive any of the interventions }\end{array}$ \\
\hline Peltola 2013 & Review article. Glycerol use discussed \\
\hline Singhi 2004 & Review article. Not a RCT \\
\hline Singhi 2007 & Letter in response to the journal editorial summary of Peltola 2007 \\
\hline Urciuoli 1963 & Mannitol tested for neurosurgical infections and not acute bacterial meningitis. Not a RCT \\
\hline Vaziri 2016 & Systematic review. Glycerol use discussed \\
\hline
\end{tabular}

CNS - central nervous system; RCT - randomised controlled trial

\section{DATA AND ANALYSES}

Comparison 1. Glycerol versus no osmotic diuretic

\begin{tabular}{lllll}
\hline $\begin{array}{l}\text { Outcome or subgroup } \\
\text { title }\end{array}$ & No. of studies & $\begin{array}{l}\text { No. of partici- } \\
\text { pants }\end{array}$ & Statistical method & Effect size \\
\hline 1 Death & 5 & 1272 & Risk Ratio (M-H, Fixed, 95\% Cl) & $1.08[0.90,1.30]$ \\
\hline 1.1 No steroids & 5 & 853 & Risk Ratio (M-H, Fixed, 95\% Cl) & $1.10[0.90,1.33]$ \\
\hline 1.2 With steroids & 3 & 419 & Risk Ratio (M-H, Fixed, 95\% Cl) & $1.02[0.60,1.74]$ \\
\hline 2 Neurological disability & 5 & 1270 & Risk Ratio (M-H, Fixed, 95\% Cl) & $0.73[0.53,1.00]$ \\
\hline
\end{tabular}

Osmotic therapies added to antibiotics for acute bacterial meningitis (Review) 


\begin{tabular}{|c|c|c|c|c|}
\hline $\begin{array}{l}\text { Outcome or subgroup } \\
\text { title }\end{array}$ & No. of studies & $\begin{array}{l}\text { No. of partici- } \\
\text { pants }\end{array}$ & Statistical method & Effect size \\
\hline 2.1 No steroids & 5 & 851 & Risk Ratio (M-H, Fixed, 95\% Cl) & $0.71[0.49,1.01]$ \\
\hline 2.2 With steroids & 3 & 419 & Risk Ratio (M-H, Fixed, 95\% Cl) & $0.82[0.38,1.77]$ \\
\hline 3 Seizures & 4 & 1090 & Risk Ratio (M-H, Fixed, 95\% Cl) & $1.08[0.90,1.30]$ \\
\hline 3.1 No steroids & 4 & 755 & Risk Ratio (M-H, Fixed, 95\% Cl) & $1.15[0.92,1.44]$ \\
\hline 3.2 With steroids & 2 & 335 & Risk Ratio (M-H, Fixed, 95\% Cl) & $0.96[0.70,1.33]$ \\
\hline 4 Hearing loss & 5 & 922 & Risk Ratio (M-H, Fixed, 95\% Cl) & $0.64[0.44,0.93]$ \\
\hline 4.1 No steroids & 4 & 572 & Risk Ratio (M-H, Fixed, 95\% Cl) & $0.63[0.41,0.99]$ \\
\hline 4.2 With steroids & 3 & 350 & Risk Ratio (M-H, Fixed, 95\% Cl) & $0.66[0.32,1.35]$ \\
\hline $\begin{array}{l}5 \text { Adverse effects: nau- } \\
\text { sea, vomiting, diarrhoea }\end{array}$ & 2 & 851 & Risk Ratio (M-H, Random, 95\% Cl) & $1.09[0.81,1.47]$ \\
\hline 5.1 No steroids & 2 & 546 & Risk Ratio (M-H, Random, 95\% Cl) & $1.22[0.81,1.83]$ \\
\hline 5.2 With steroids & 1 & 305 & Risk Ratio (M-H, Random, 95\% Cl) & $0.86[0.66,1.13]$ \\
\hline $\begin{array}{l}6 \text { Adverse effects: gas- } \\
\text { trointestinal bleeding }\end{array}$ & 3 & 607 & Risk Ratio (M-H, Random, 95\% Cl) & $0.93[0.39,2.19]$ \\
\hline 6.1 No steroids & 3 & 296 & Risk Ratio (M-H, Random, 95\% Cl) & $0.39[0.06,2.60]$ \\
\hline 6.2 With steroids & 3 & 311 & Risk Ratio (M-H, Random, 95\% Cl) & $1.16[0.44,3.04]$ \\
\hline
\end{tabular}

Analysis 1.1. Comparison 1 Glycerol versus no osmotic diuretic, Outcome 1 Death.

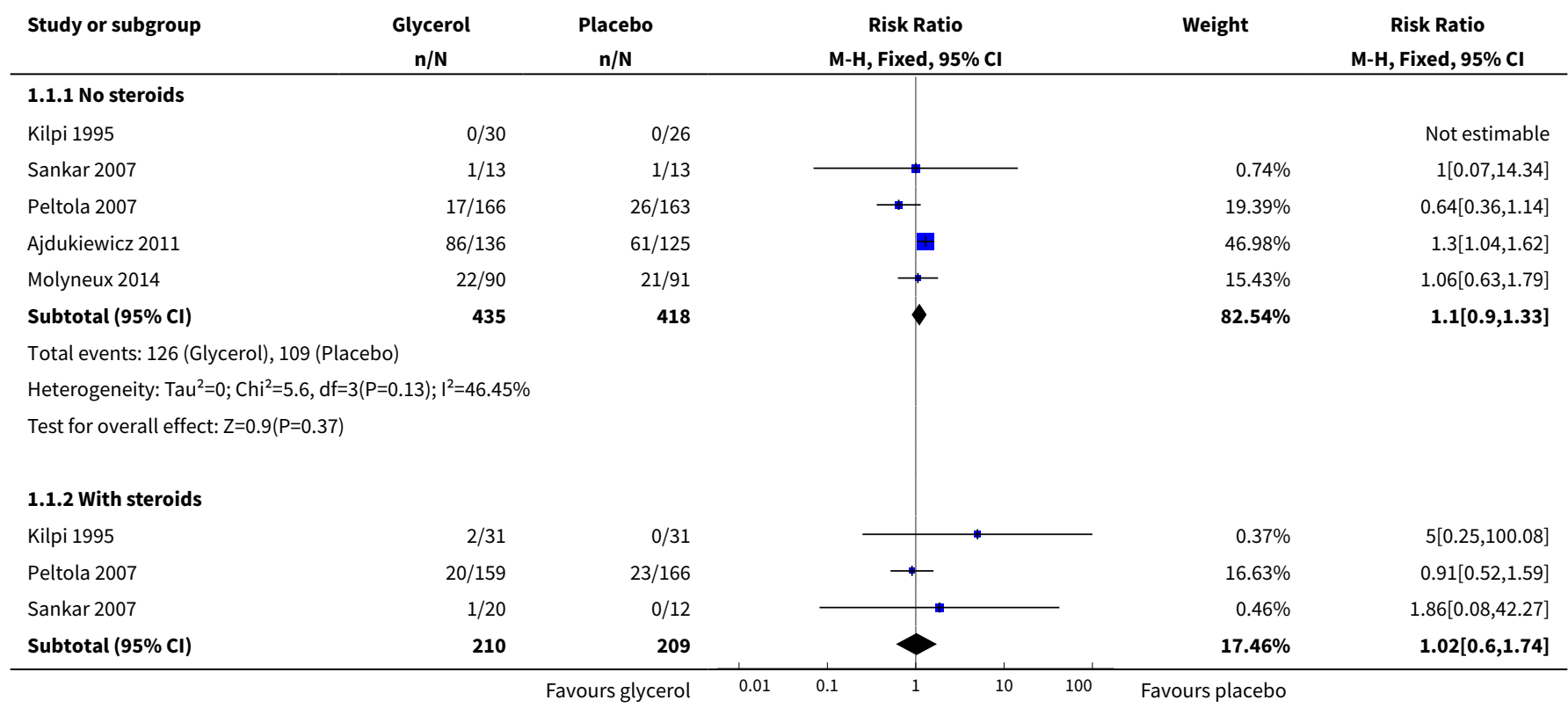




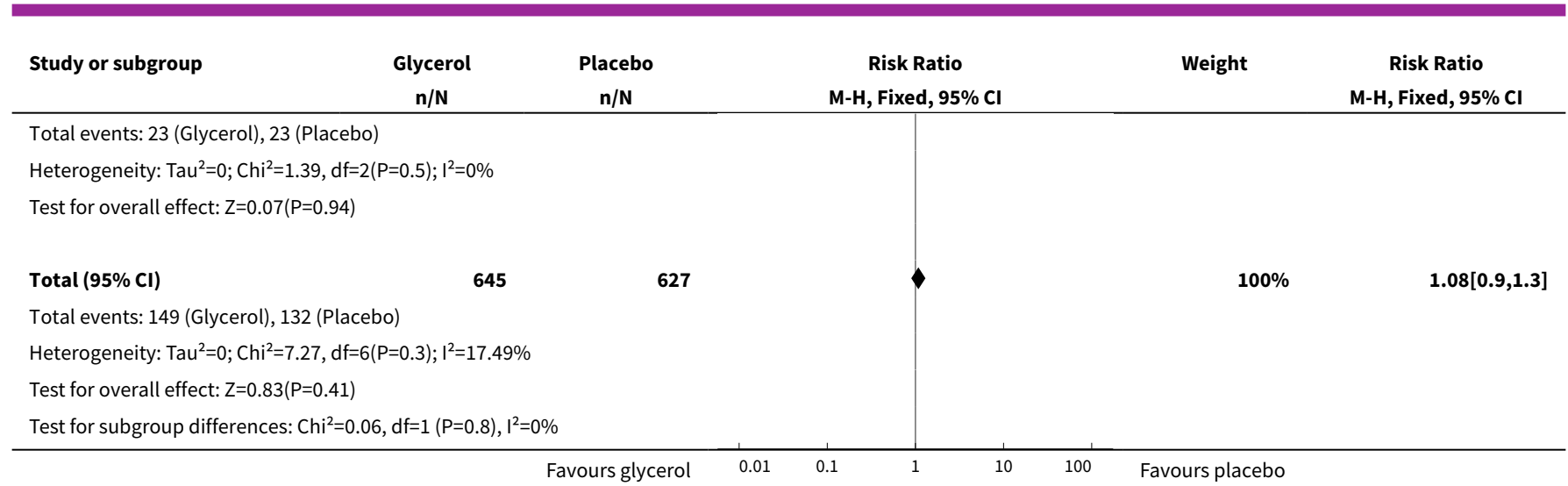

\section{Analysis 1.2. Comparison 1 Glycerol versus no osmotic diuretic, Outcome 2 Neurological disability.}

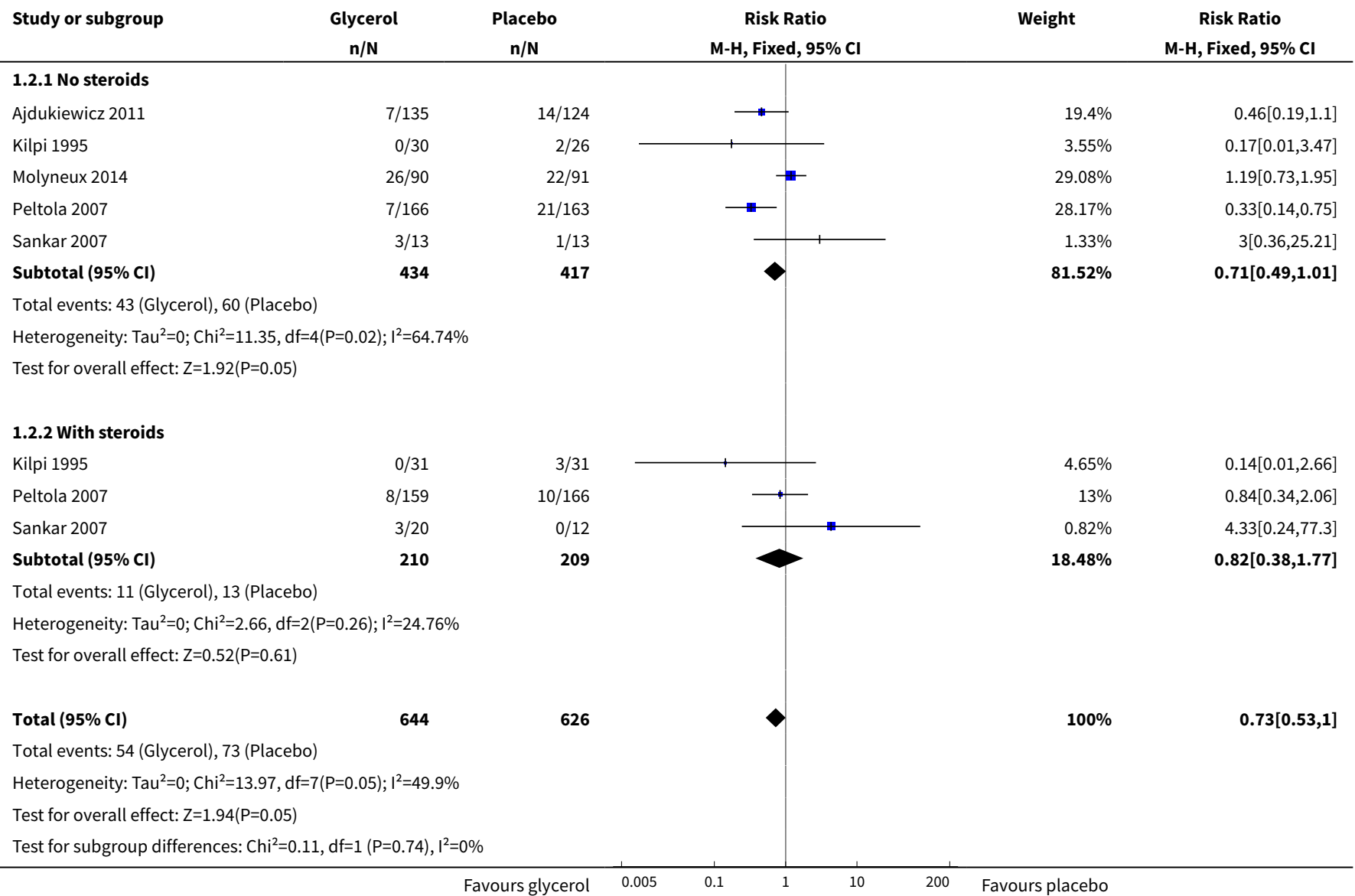

Analysis 1.3. Comparison 1 Glycerol versus no osmotic diuretic, Outcome 3 Seizures.

\begin{tabular}{|c|c|c|c|c|c|c|c|c|}
\hline \multirow{2}{*}{$\begin{array}{l}\text { Study or subgroup } \\
\text { 1.3.1 No steroids }\end{array}$} & \multirow[t]{2}{*}{$\begin{array}{c}\text { Glycerol } \\
\mathrm{n} / \mathrm{N}\end{array}$} & \multirow[t]{2}{*}{$\begin{array}{c}\text { Placebo } \\
\mathrm{n} / \mathrm{N}\end{array}$} & \multicolumn{3}{|c|}{$\begin{array}{c}\text { Risk Ratio } \\
\text { M-H, Fixed, 95\% CI }\end{array}$} & & \multirow[t]{2}{*}{ Weight } & \multirow[t]{2}{*}{$\begin{array}{c}\text { Risk Ratio } \\
\text { M-H, Fixed, 95\% C }\end{array}$} \\
\hline & & & & & & & & \\
\hline
\end{tabular}

Osmotic therapies added to antibiotics for acute bacterial meningitis (Review) 


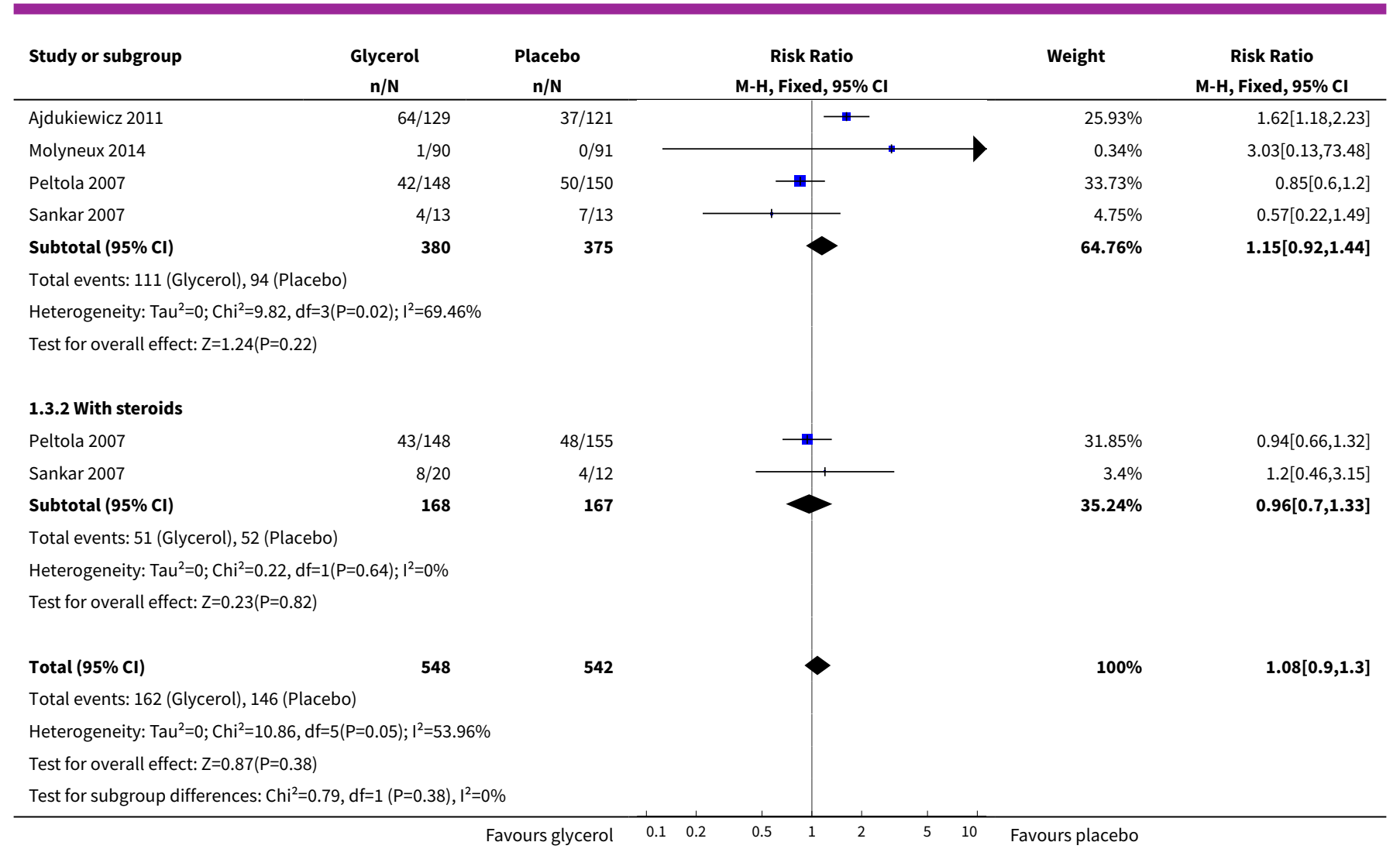

Analysis 1.4. Comparison 1 Glycerol versus no osmotic diuretic, Outcome 4 Hearing loss.

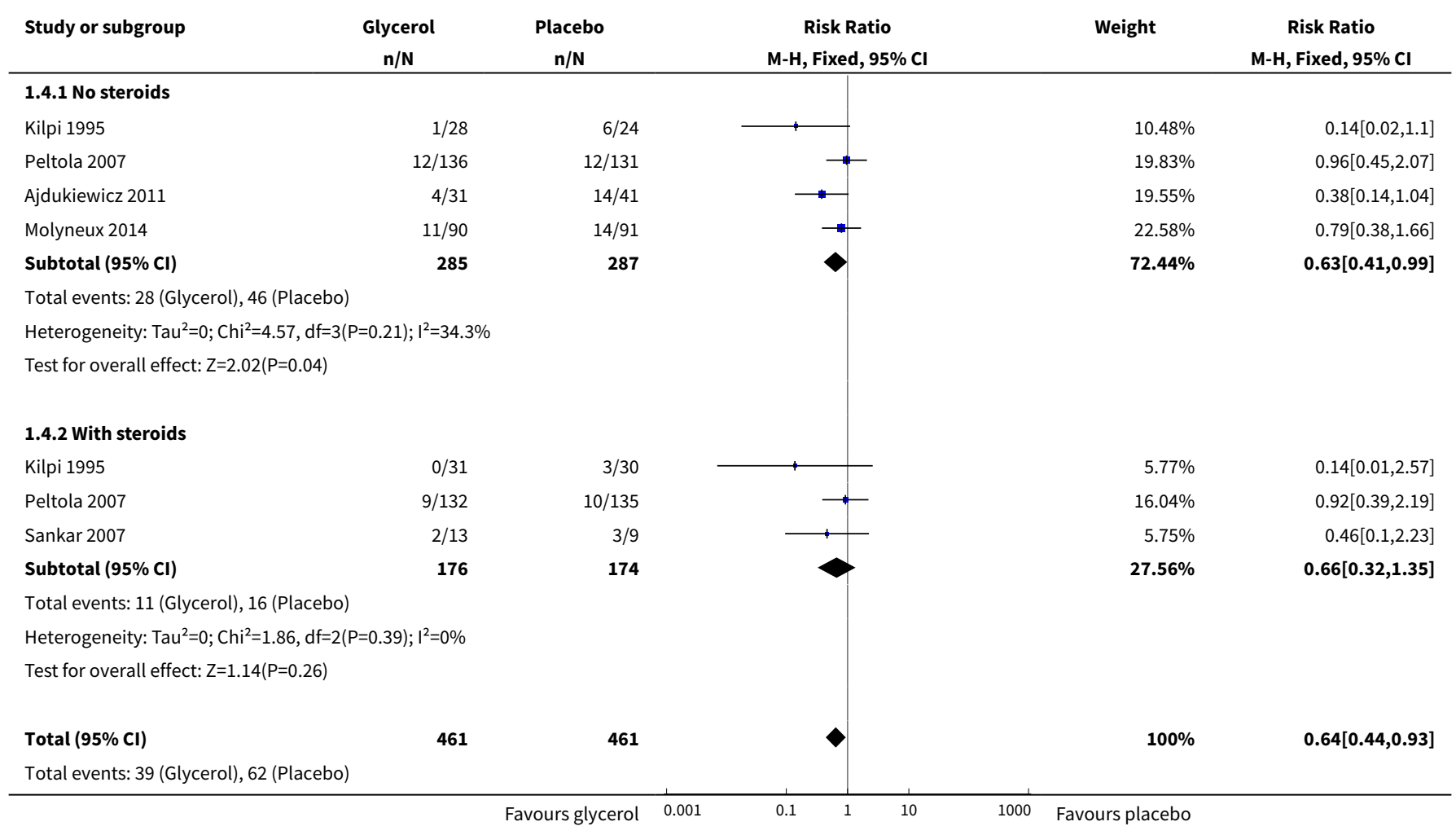




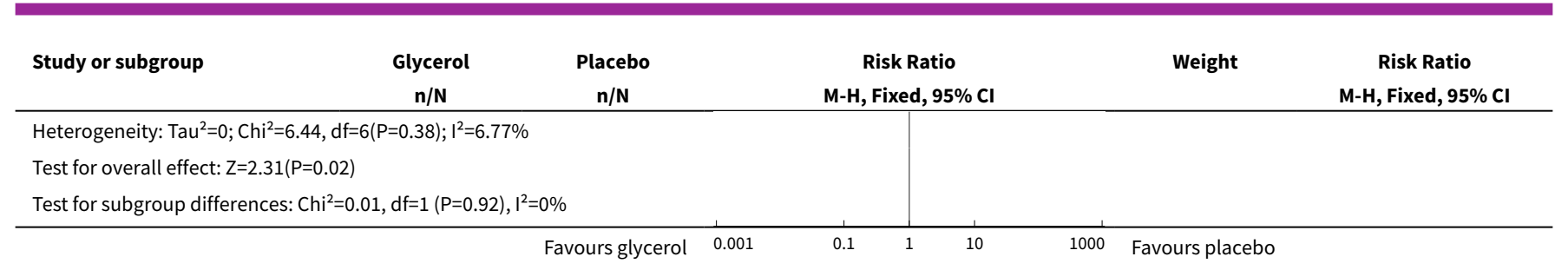

Analysis 1.5. Comparison $1 \mathrm{Glycerol}$ versus no osmotic diuretic, Outcome 5 Adverse effects: nausea, vomiting, diarrhoea.

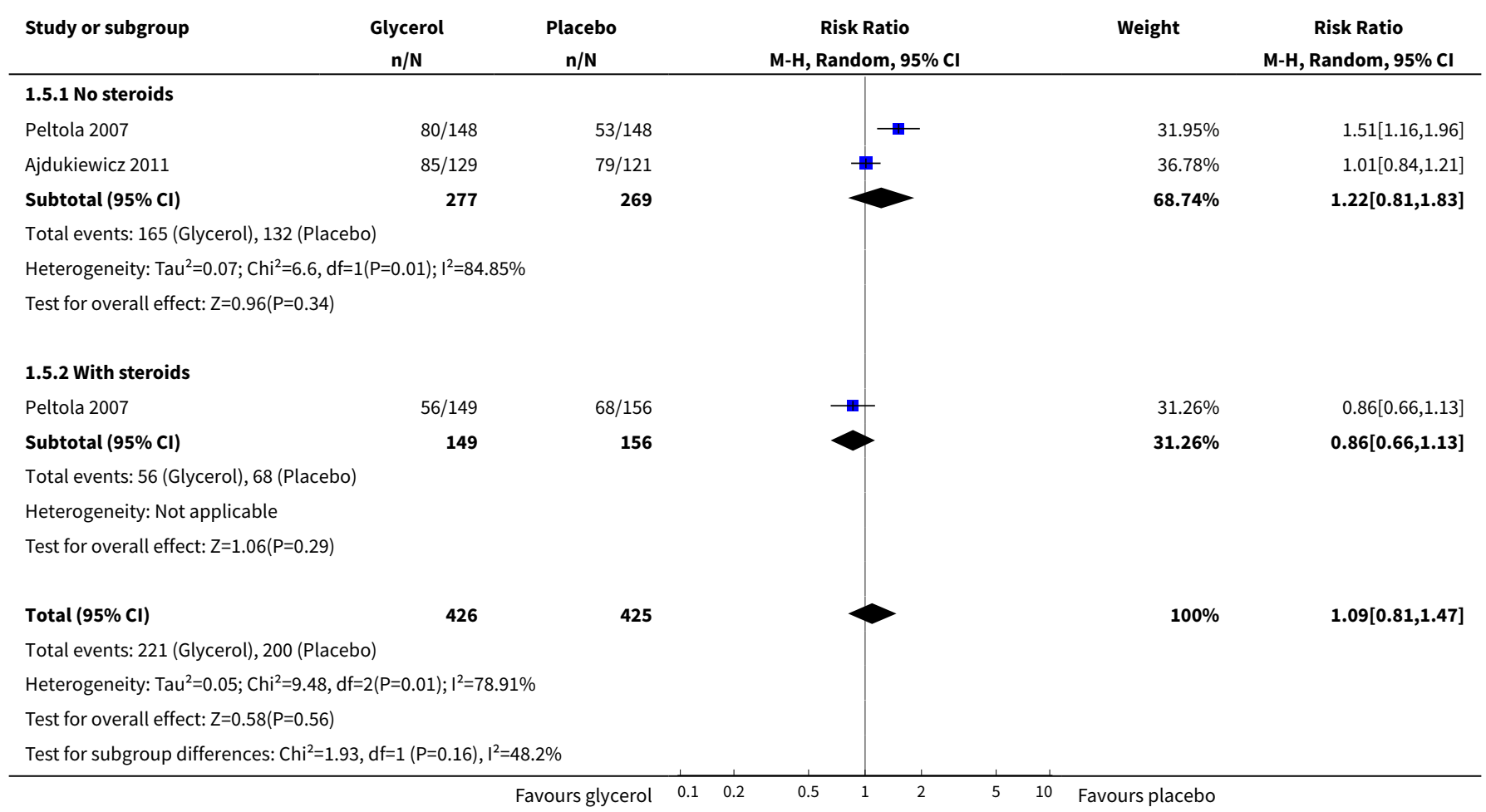

Analysis 1.6. Comparison $1 \mathrm{Glycerol}$ versus no osmotic diuretic, Outcome 6 Adverse effects: gastrointestinal bleeding.

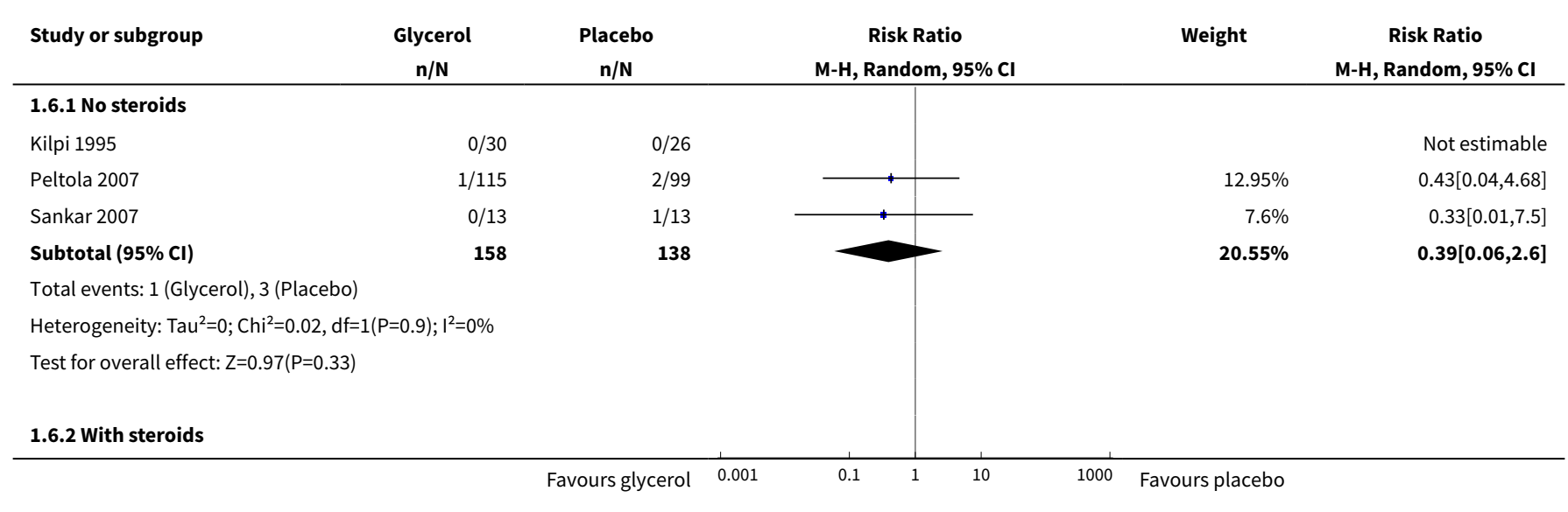




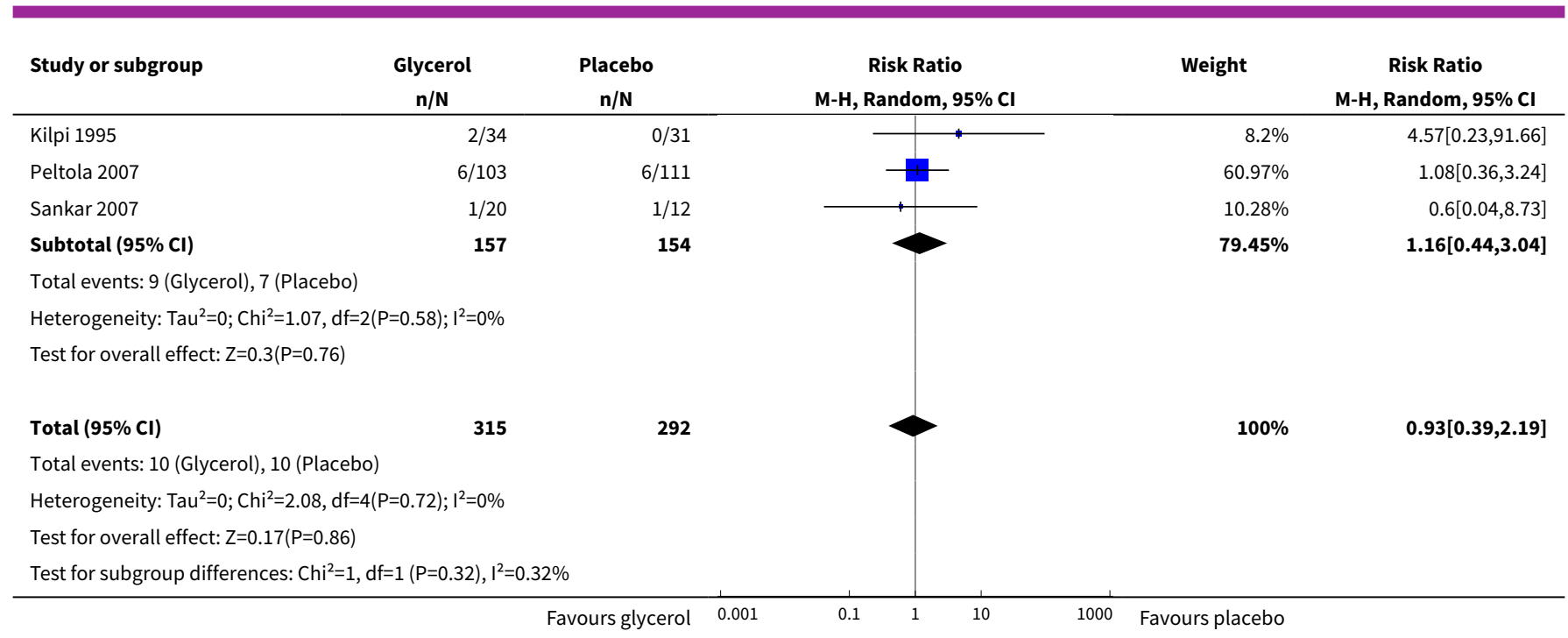

\section{ADDITIONAL TABLES}

Table 1. Available osmotic therapies

\begin{tabular}{|c|c|c|c|c|}
\hline Drug & Class & Mechanism of action & $\begin{array}{l}\text { Dose range and } \\
\text { route }\end{array}$ & Studied/used in \\
\hline Glycerol & Sugar alcohol & $\begin{array}{l}\text { Probably osmosis plus } \\
\text { possible vascular and } \\
\text { metabolic benefit }\end{array}$ & $\begin{array}{l}\text { IV } 5 \% \text { to } 10 \% \text { solu- } \\
\text { tion or } 50 \mathrm{~g} \\
\text { Oral } 1.5 \mathrm{~g} / \mathrm{kg}\end{array}$ & $\begin{array}{l}\text { Meningitis (Peltola 2007), stroke (Righetti } \\
\text { 2004) }\end{array}$ \\
\hline Mannitol & Sugar alcohol & Osmotic diuretic & $\begin{array}{l}\text { IV } 20 \% \text { solution } \\
1 \mathrm{~mL} / \mathrm{kg} \text { to } 10 \mathrm{~mL} / \\
\mathrm{kg} \text { or } 1 \mathrm{~g} / \mathrm{kg}\end{array}$ & $\begin{array}{l}\text { Brain trauma (Wakai 2013), cerebral malar- } \\
\text { ia (Namutangula 2007), stroke (Bereczki } \\
\text { 2007) }\end{array}$ \\
\hline Sorbitol & Sugar alcohol & $\begin{array}{l}\text { Osmotic diuretic } \\
\text { (weak) }\end{array}$ & Oral, IV & Experimental brain perfusion, stroke \\
\hline $\begin{array}{l}\text { Hypertonic } \\
\text { saline }\end{array}$ & $\begin{array}{l}\text { Hypertonic solu- } \\
\text { tions }\end{array}$ & Osmosis & IV & $\begin{array}{l}\text { Brain trauma (Choi 2005), stroke (Schwarz } \\
\text { 2002) }\end{array}$ \\
\hline $\begin{array}{l}\text { Sodium } \\
\text { lactate }\end{array}$ & Hydroxy acids & Osmosis (weak) & IV & Brain trauma (Ichai 2009) \\
\hline
\end{tabular}

IV: intravenous

Table 2. Comparison of included study interventions

\begin{tabular}{lllll}
\hline $\begin{array}{l}\text { Name of } \\
\text { study }\end{array}$ & Population & Intervention and dose & Control used & $\begin{array}{l}\text { Treatment } \\
\text { duration }\end{array}$
\end{tabular}


Table 2. Comparison of included study interventions (Continued)

\begin{tabular}{|c|c|c|c|c|c|}
\hline Kilpi 1995 & $\begin{array}{l}\text { Children in } \\
\text { Finland }\end{array}$ & $\begin{array}{l}\text { Oral glycerol } 4.5 \mathrm{~g} / \mathrm{kg} \text { max } \\
180 \mathrm{~g} / 24 \mathrm{~h} \text { in } 3 \text { divided } \\
\text { doses } \\
\text { Dexamethasone (dex) } 1.5 \\
\mathrm{mg} / \mathrm{kg} \text { max } 60 \mathrm{mg} / \text { day }\end{array}$ & $\begin{array}{l}\text { No oral place- } \\
\text { bo } \\
\text { IV saline }\end{array}$ & 3 days & $\begin{array}{l}4 \text { arms: IV dexamethasone + } \\
\text { glycerol, oral glycerol, IV dex- } \\
\text { amethasone, neither treatment }\end{array}$ \\
\hline Sankar 2007 & $\begin{array}{l}\text { Children in In- } \\
\text { dia }\end{array}$ & $\begin{array}{l}\text { Oral glycerol } 1.5 \mathrm{~g} / \mathrm{kg} 3 \mathrm{x} \\
\text { daily } \\
\text { Dexamethasone } 0.15 \mathrm{mg} / \\
\text { kg } 3 \text { x daily }\end{array}$ & $\begin{array}{l}\text { Oral car- } \\
\text { boxymethyl- } \\
\text { cellulose 2\% } \\
\text { IV saline }\end{array}$ & Not detailed & $\begin{array}{l}4 \text { arms: placebo oral and IV, IV } \\
\text { dexamethasone + oral glycerol, } \\
\text { IV placebo + oral glycerol, IV } \\
\text { dexamethasone + oral placebo }\end{array}$ \\
\hline Peltola 2007 & $\begin{array}{l}\text { Children in } \\
\text { South Ameri- } \\
\text { ca }\end{array}$ & $\begin{array}{l}\text { Oral glycerol } 1.5 \mathrm{~g} / \mathrm{kg} 3 \mathrm{x} \\
\text { daily } \\
\text { Dexamethasone } 0.15 \mathrm{mg} / \\
\text { kg } 3 \times \text { daily }\end{array}$ & $\begin{array}{l}\text { Oral car- } \\
\text { boxymethyl- } \\
\text { cellulose } 2 \% \\
\text { IV saline }\end{array}$ & 2 days & $\begin{array}{l}4 \text { arms: oral and IV placebo, IV } \\
\text { dexamethasone + oral glycerol, } \\
\text { IV placebo + oral glycerol, IV } \\
\text { dexamethasone + oral placebo }\end{array}$ \\
\hline $\begin{array}{l}\text { Ajdukiewicz } \\
2011\end{array}$ & $\begin{array}{l}\text { Adults in } \\
\text { Malawi, } \\
\text { Southern } \\
\text { Africa }\end{array}$ & $\begin{array}{l}\text { Oral glycerol } 75 \mathrm{mg} 4 \mathrm{x} \text { dai- } \\
\text { ly diluted in water or } 50 \% \\
\text { dextrose solution }\end{array}$ & $\begin{array}{l}\text { Oral } 50 \% \text { dex- } \\
\text { trose solution }\end{array}$ & 4 days & $\begin{array}{l}\text { Oral glycerol versus oral } 50 \% \\
\text { dextrose }\end{array}$ \\
\hline $\begin{array}{l}\text { Molyneux } \\
2014\end{array}$ & $\begin{array}{l}\text { Children } \\
\text { in Malawi, } \\
\text { Southern } \\
\text { Africa }\end{array}$ & $\begin{array}{l}\text { Oral glycerol } 25 \mathrm{~mL} / \text { dose } \\
\text { (maximum dose) = } 100 \\
\mathrm{~mL} / 24 \text { hours. } \\
\text { Acetaminophen } 35 \mathrm{mg} / \mathrm{kg} \\
\text { 6-hourly }\end{array}$ & $\begin{array}{l}\text { Oral car- } \\
\text { boxymethyl- } \\
\text { cellulose } 2 \%\end{array}$ & 2 days & $\begin{array}{l}3 \text { arms: oral glycerol and oral } \\
\text { acetaminophen, oral place- } \\
\text { bo and glycerol, oral aceta- } \\
\text { minophen and oral placebo }\end{array}$ \\
\hline
\end{tabular}

IV: intravenous

\section{APPENDICES}

\section{Appendix 1. MEDLINE (Ovid) search strategy}

1 exp Meningitis/

2 meningit*.tw.

31 or 2

4 Osmosis/

5 Osmotic Pressure/

6 exp Diuretics, Osmotic/

7 (osmos $^{\star}$ or osmot ${ }^{\star}$ or osmol ${ }^{\star}$ ).tw.

8 exp Sugar Alcohols/

9 glycer $^{\star}$. tw,nm.

10 1,2,3-propanetrio*.tw,nm.

11 mannitol ${ }^{*} . \mathrm{tw}, \mathrm{nm}$.

12 sorbit*.tw,nm.

13 Sodium Lactate/

14 (sodium adj2 lactat ${ }^{\star}$ ).tw,nm.

15 Saline Solution, Hypertonic/

16 (hypertonic adj2 saline ${ }^{\star}$ ).tw,nm.

17 or/4- 16

183 and 17

\section{Appendix 2. Embase (Elsevier) search strategy}

\#20 \#16 AND \#19

Osmotic therapies added to antibiotics for acute bacterial meningitis (Review) 
\#19 \#17 OR \#18

\#18 random*:ab,ti OR placebo*:ab,ti OR factorial*:ab,ti OR crossover*ab,ti OR 'cross over':ab,ti OR 'cross-over':ab,ti OR assign*:ab,ti OR allocat*:ab,ti OR volunteer*:ab,ti OR ((doubl* OR singl*) NEAR/2 (blind* OR mask $\left.\left.{ }^{\star}\right)\right)$ :ab,ti

\#17 'randomized controlled trial'/exp OR 'single blind procedure'/exp OR 'double blind procedure'/exp OR 'crossover procedure'/exp

\#16 \#3 AND \#15

\#15 \#4 OR \#5 OR \#6 OR \#7 OR \#8 OR \#9 OR \#10 OR \#11 OR \#12 OR \#13 OR \#14

\#14 (hypertonic NEAR/2 saline):ab,ti

\#13 'sodium chloride'/de

\#12 (lactat ${ }^{\star}$ NEAR/2 sodium):ab,ti

\#11 'lactate sodium'/de

\#10 sorbit ${ }^{\star}: a b, t i$

\#9 mannitol*:ab,ti

\#8 '1,2,3-propanetriol':ab,ti OR propanetrio*:ab,ti

$\# 7$ glycer*:ab,ti

\#6 'sugar alcohol'/exp

\#5 osmotic*:ab,ti

\#4 'osmotic diuretic agent'/exp

\#3 \#1 OR \#2

\#2 meningit*:ab,ti

$\# 1$ 'meningitis'/exp

\section{Appendix 3. CINAHL (Ebsco) search strategy}

\section{S12 S3 and S11}

$\mathrm{S} 11 \mathrm{~S} 4$ or $\mathrm{S} 5$ or $\mathrm{S} 6$ or $\mathrm{S} 7$ or $\mathrm{S} 8$ or $\mathrm{S} 9$ or $\mathrm{S} 10$

$\mathrm{S} 10 \mathrm{TI}$ hypertonic $\mathrm{N} 2$ saline or $\mathrm{AB}$ hypertonic $\mathrm{N} 2$ saline

S9 (MH "Saline Solution, Hypertonic")

S8 TI sodium N2 lactat* or AB sodium N2 lactat*

S7 TI ( glycerol ${ }^{\star}$ or 1,2,3-propanetriol or propanetriol* or mannitol* or sorbit* ) or AB ( glycerol* or 1,2,3-propanetriol or propanetriol ${ }^{\star}$ or mannitol* or sorbit*)

S6 AB sugar alcohol* or TI sugar alcohol*

S5 (MH "Sugar Alcohols+")

S4 TI osmotic* or AB osmotic*

S3 S1 or S2

S2 TI meningit* or AB meningit*

S1 (MH "Meningitis+")

\section{Appendix 4. LILACS (BIREME) search strategy}

> Search > (MH:Meningitis OR Meningite OR MH:C10.228.228.507\$ OR C10.228.566\$ OR MH:C01 252.200\$ OR C10.228.228.180.500\$ OR meningit\$) AND (MH:"Diuretics, Osmotic" OR "Diuréticos Osmóticos" OR "Diuréticos Osmóticos" OR "Osmotic Diuretics" OR MH:D27.505.696.560.500.453\$ OR osmot\$ OR osmos\$ OR osmol\$ OR MH:"Sugar Alcohols" OR "Alcoholes del Azúcar" OR "Álcoois de Açúcar" OR MH:D02.033.800\$ OR MH:D09.853\$ OR "sugar alcohols" OR glycer\$ OR "1,2,3-propanetriol" OR mannitol\$ OR sorbit\$ OR MH:"Sodium Lactate" OR "Lactato de Sodio" OR "Lactato de Sódio" OR MH:D02.241.511.459.500\$ OR "sodium lactate" OR MH:"Saline Solution, Hypertonic" OR "Solución Salina Hipertónica" OR "Solução Salina Hipertônica" OR "Hypertonic Saline Solution" OR "Sodium Chloride Solution, Hypertonic" OR "Hypertonic Solution, Saline" OR "Solución Hipertónica de Cloruro de Sodio" OR "Solução Hipertônica de Cloreto de Sódio" OR "hypertonic saline") > clinical_trials

\section{Appendix 5. ClinicalTrials.gov search strategy}

Search terms: (meningitis OR meningitides) AND (osmosis or osmoses or osmotic or osmolarity or glycerol OR glycerine OR glycerin OR or 1,2,3-propanetriol or propanetriol or mannitol or sorbitol or sodium lactate or (hypertonic AND saline))

\section{Appendix 6. WHO ICTRP search strategy}

Search terms: meningit* AND osmos* or meningit* AND osmot* OR meningit* AND osmol* or meningit ${ }^{\star}$ AND glycer* OR meningit ${ }^{\star}$ AND 1,2,3-propanetrio ${ }^{\star}$ or meningit ${ }^{\star}$ AND mannitol ${ }^{\star}$ or meningit ${ }^{\star}$ AND sorbit ${ }^{\star}$ or meningit ${ }^{\star}$ AND sodium lactate or meningit ${ }^{\star}$ AND hypertonic AND saline*

\section{WHAT'S NEW}




\begin{tabular}{lll}
\hline Date & Event & Description \\
\hline 3 September 2017 & New search has been performed & $\begin{array}{l}\text { We updated our searches. We included one new trial (Molyneux } \\
\text { 2014) and excluded six new trials (CTRI/2015/04/005668; Glimåk- } \\
\text { er 2014; Kumar 2014; Molyneux 2015; Peltola 2013; Vaziri 2016). }\end{array}$ \\
& $\begin{array}{l}\text { We added adverse events as an outcome and presented death } \\
\text { and neurological disability separately. }\end{array}$ \\
\hline 17 February 2017 & $\begin{array}{l}\text { A new author joined the team to complete this update (Hanna } \\
\text { Bergman). }\end{array}$ & Our conclusions remain unchanged. \\
\hline
\end{tabular}

\section{CONTRIBUTIONSOF AUTHORS}

Emma Wall (EW) was responsible for writing the main text, extracting data from studies and reviewing the analyses; Paul Garner (PG) was responsible for methodological input, help with interpretation and writing the review; Katherine Ajdukiewicz (KA) was responsible for updating the main text, extracting data from studies and updating the analyses with new data, and commented on the text; Robert Heyderman (RH) provided comments on the text; Hannah Bergman carried out data extraction and updated this review.

\section{DECLARATIONSOF INTEREST}

Emma Wall: none known.

Katherine Ajdukiewicz: none known.

Hanna Bergman: works for Cochrane Response, a healthcare evidence consultancy that take commissions from healthcare guideline developers and policy makers. Hanna received payment for updating this review from UKAID through the grant held by PG.

Robert Heyderman: none known

Paul Garner: This review and the salary of PG is supported by UKAID aimed at ensuring systematic reviews, particularly Cochrane Reviews, are completed on topics relevant to the poor in low- and middle-income countries (grant number 5242). UKAID does not participate in the selection of topics, in the conduct of the review or in the interpretation of findings.

\section{SOURCES OF SUPPORT}

\section{Internal sources}

- Clare Dooley, Australia.

Editorial and secretarial

- Liz Dooley, Australia.

Editorial

- Sarah Thorning, Australia.

Library and searching support

- Dr David Sinclair, UK.

Data support

\section{External sources}

- Wellcome Trust, UK.

Award: 089671/B/09/Z

- UKAID Grant 5242, UK.

UKAID does not participate in the selection of topics, in the conduct of the review or in the interpretation of findings 


\section{DIFFERENCES BETWEEN PROTOCOL AND REVIEW}

In the 2017 update, we presented death and disability separately. In the earlier version of this review, this was a composite outcome. We believe this provides greater clarity for patients and clinicians.

\section{INDEX TERMS}

\section{Medical Subject Headings (MeSH)}

Adrenal Cortex Hormones [therapeutic use]; Anti-Bacterial Agents [therapeutic use]; Combined Modality Therapy [methods]; Community-Acquired Infections [complications] [metabolism] [mortality] [therapy]; Deafness [epidemiology] [prevention \& control]; Dexamethasone [therapeutic use]; Diuretics, Osmotic [adverse effects] [*therapeutic use]; Epilepsy [prevention \& control]; Gastrointestinal Hemorrhage [prevention \& control]; Glucose [therapeutic use]; Glycerol [adverse effects] [ ${ }^{\star}$ therapeutic use]; Intracranial Pressure [physiology]; Meningitis, Bacterial [complications] [metabolism] [mortality] [^therapy]; Nervous System Diseases [epidemiology] [prevention \& control]; Osmosis [physiology]; Osmotic Pressure [physiology]; Randomized Controlled Trials as Topic

\section{MeSH check words}

Adolescent; Adult; Child; Humans 